\title{
Characteristics and Management Implications of the Spring Waterfowl Hunt in the Western Canadian Arctic, Northwest Territories
}

\author{
ROBERT G. BROMLEY ${ }^{1}$
}

\author{
(Received 27 June 1995; accepted in revised form 30 October 1995)
}

\begin{abstract}
The species composition, timing of the harvest, sex, age, breeding status, and numbers of geese and swans shot during the spring hunt by residents of Tuktoyaktuk, Paulatuk, and Sachs Harbour, Northwest Territories were studied in each community hunting area for three consecutive years (1987 to 1990). Investigators visited hunters repeatedly in the field, conducting interviews and examining $\geq 27 \%$ of the reported harvest. Snow geese (Anser caerulescens caerulescens) accounted for $70 \%$ of the harvest, followed by white-fronted geese (Anser albifrons frontalis, 19\%), Canada geese (Branta canadensis hutchinsii, 5\%), brant (Branta bernicla nigricans, 4\%), tundra swans (Cygnus columbianus, 2\%), and Ross' geese (Anser rossii, $<1 \%$ ). Sex ratios varied by species and community. Age ratios (yearlings per adult) also varied, and were inversely correlated with the size of the previous year's continental recreational harvest for white-fronted geese. Breeding status of geese with adult plumage varied, but was generally near $80 \%$ breeders. Average annual harvests of geese and swans were estimated at 5986 for Tuktoyaktuk, 1605 for Paulatuk, and 2790 for Sachs Harbour. Regional spring harvests, as a percent of continental harvests of regional populations, were $19 \%$ for lesser snow geese and $15 \%$ for white-fronted geese. Harvest levels require consideration in all stages of management of the resource, from local to continental. Action is required in Canada, through cooperative wildlife management mechanisms of the Inuvialuit Final Agreement and other land claims legislation, and through new regional bodies, to ensure that the spring harvest is incorporated into regional, national and international management of migratory birds.
\end{abstract}

Key words: native harvest survey, snow goose, white-fronted goose, tundra swan, Western Arctic, Inuvialuit, subsistence harvest, Northwest Territories, spring hunt

RÉSUMÉ. Durant trois années consécutives (de 1987 à 1990), on a étudié la composition des espèces, le moment des prélèvements, le sexe, l'âge, le statut de reproducteur et le nombre d'oies et de cygnes tués par balle au cours de la chasse printanière par les résidents de Tuktoyaktuk, de Paulatuk et de Sachs Harbour (Territoires du Nord-Ouest) dans la zone de chasse de chacune de ces communautés. Les chercheurs ont à plusieurs reprises rendu visite aux chasseurs sur le terrain, mené des entrevues et examiné $\geq 27$ p. cent des prélèvements rapportés. L'oie des neiges (Anser caerulescens caerulescens) comptait pour 70 p. cent des prélèvements, suivie de l'oie à front blanc (Anser albifrons frontalis, 19 p. cent), de la bernache du Canada (Branta canadensis hutchinsii, 5 p. cent), de la bernache noire (Branta bernicla nigricans, 4 p. cent), du cygne siffleur (Cygnus columbianus, 2 p. cent), et de l'oie de Ross (Anser rossii, < 1 p. cent). Le taux mâle / femelle variait suivant les espèces et la communauté. Le taux entre les âges (nombre de petits d'un an par adulte) variait aussi, et était corrélé inversement pour l'oie à front blanc avec le nombre d'oiseaux prélevés au cours de la chasse sportive de l'année précédente à l'échelle du continent. Le statut de reproducteur des oies ayant un plumage d'adulte variait, mais en général, près de 80 p. cent étaient des oiseaux reproducteurs. On a évalué la moyenne des prélèvements annuels d'oies et de cygnes à 5986 pour Tuktoyaktuk, 1605 pour Paulatuk et 2790 pour Sachs Harbour. Les prélèvements printaniers régionaux, en tant que pourcentage des prélèvements de populations régionales à l'échelle du continent, étaient de $19 \mathrm{p}$. cent pour la petite oie des neiges et de $15 \mathrm{p}$. cent pour l'oie à front blanc. Il faut porter attention au niveau des prélèvements à tous les stades de la gestion des ressources, du niveau local au niveau du continent tout entier. Des mesures doivent être prises au Canada, par le biais des mécanismes de coopération de gestion de la faune contenus dans la Convention définitive des Inuvialuit et d'autres lois relatives aux revendications territoriales, ainsi que par le biais de nouvelles instances régionales, pour assurer que les prélèvements printaniers soient intégrés dans une gestion régionale, nationale et internationale des oiseaux migrateurs.

Mots clés: relevés des prélèvements autochtones, oie des neiges, oie à front blanc, cygne siffleur, Arctique occidental, Inuvialuit, prélèvements de subsistance, Territoires du Nord-Ouest, chasse printanière

Traduit pour la revue Arctic par Nésida Loyer.

\footnotetext{
${ }^{1}$ Department of Renewable Resources, Government of the Northwest Territories, 600, 5102 - 50th Avenue, Yellowknife, Northwest Territories X1A 3S8

(C) The Arctic Institute of North America
} 


\section{INTRODUCTION}

The Migratory Birds Convention of 1916 between Great Britain (for Canada) and the United States was developed to protect the North American migratory bird resource from declining because of habitat loss and overhunting. The destructive nature of spring hunting, especially market hunting in the United States and on the Canadian prairies, was of primary concern (Hewitt, 1921). Few provisions were made in the convention, however, for the people who depend on migratory birds for sustenance during the closed season, from 11 March to 31 August, stipulated in the convention. This was of particular concern to residents of the far North, because waterfowl arrived after the legal season closed, and most departed before the season opened. Those few birds that remained had accumulated little fat, and were therefore of less nutritional value than those taken in the spring, when birds arrived with abundant fat reserves. With the exception of some communities where the Royal Canadian Mounted Police maintained a permanent presence, harvests continued at traditional levels and times. An informal policy of nonenforcement generally prevailed, and was finally formalized in 1991 (Environment Canada, 1991).

Relative to the implementation of the Migratory Birds Convention Act in 1918, interest in documenting the spring harvest of waterfowl in Canada is recent (e.g., Hanson and Smith [1950] and Hanson and Currie [1957] are considered pioneering investigators in this area), and began with recognition that spring harvests could be substantial, and should be acknowledged in the management of continental populations (Boyd, 1977; Berkes, 1982). During the initial studies, retrieving information from spring hunters to document the size and characteristics of the harvest (e.g., Hanson and Currie, 1957; Klein, 1966; Macaulay and Boag, 1974), was a less sensitive operation than it is today. However, as enforcement of hunting restrictions was attempted and public statements condemning the hunt were made (e.g., Williams, 1986), spring hunters became more aware of concerns relating to the spring harvest of waterfowl. Consequently, hunters became reluctant to share information on the harvest, and biologists less eager to try to document the take. This is unfortunate, because increasingly detailed and accurate information is needed to successfully manage the continental waterfowl resource (Boyd, 1977; Raveling, 1984). Recent resolutions of some native land claims and court judgements in the area of native subsistence rights indicate that some spring access to waterfowl will continue indefinitely for at least some people (Thompson, 1991). Similarly, the North American Waterfowl Management Plan (Environment Canada, 1986) reflects a recognition of the legitimacy and value of a subsistence harvest. With new and open recognition of the validity of spring hunting, and with cooperative management regimes established in land claim settlements (Swerdfager, 1992), discussions between resource users and management biologists in Canada are beginning anew.

Although knowledge of the spring hunt is required for responsible management of continental waterfowl populations, it is clear that, to those involved, the hunt means much more than the simple taking of birds (Hanson and Currie, 1957; Klein, 1966; Barry and Carpenter, 1983; Raveling, 1984). To Northerners, the spring hunt is an essential, renewing contact with the land. To be successful, any thought given to managing this hunt must incorporate sensitivities to the socially and spiritually renewing aspects of this time of year and activity. Management of the hunt must be integrated with resource management range-wide, and spring hunting groups must be involved in management decisions (Raveling, 1984; Laycock, 1985; Cournoyea and Bromley, 1986; Swerdfager, 1992).

Most studies of spring harvests have concentrated on species and numbers of birds harvested (e.g., James Bay and Northern Quebec Native Harvesting Research Committee, 1982; Prevett et al., 1983). The Inuvialuit Harvest Study, conducted concomitant to this study, also focused on species and numbers of all wildlife harvested, including birds, with monthly estimates throughout the year (Fabijan, 1991a, b, c). While there has been considerable effort to document the effects of fall harvests on waterfowl populations and their productivity (e.g., Anderson and Burnham, 1976; Anderson et al., 1982), there have been few parallel attempts to determine the effects of a spring harvest, beyond the effect of numbers shot.

The perspective of this study was that there will at some time be a need to protect certain stocks of birds, and that managers will need to be aware of opportunities to minimize impacts of a spring harvest on one segment of the resource while still allowing some harvest to occur. That is, what can we do on the northern end of the birds' range to prevent or mitigate both the socioeconomic and the biological costs associated with major resource depletion (Raveling, 1984)? Alternatively, how can we provide legitimate access where new and sustainable opportunities for harvest exist? Canada and the United States recently negotiated a Protocol to Amend the Migratory Birds Convention that, having been approved by the Canadian Cabinet in September 1995, and if ratified by the United States Senate, will conserve stocks by placing the spring harvest within a legal and responsible management regime (Thompson, 1991; Brackett, 1995). However, for this amendment to become effective, further knowledge about characteristics of the contemporary spring hunt is required (Bromley, 1987).

In recognition of these needs, and of the importance of the spring waterfowl hunt to people of the Northwest Territories, studies of the characteristics of the spring harvest were conducted in the communities of Tuktoyaktuk, Paulatuk, and Sachs Harbour, Northwest Territories (Fig. 1). Because there is extensive information on the impact of fall harvests upon populations, and because fall harvests in these communities were smaller than the spring take (Fabijan, 1991a,b,c), research was focused on the spring hunt only.

Objectives were to determine numbers, species, sex and age composition, and breeding status of birds harvested (struck and retrieved) in spring; to compare the estimated harvest to regional populations and continental harvest 
characteristics of those populations; to examine trends in the harvest; and to identify factors affecting the harvest. This study is only a first step toward better understanding of the spring hunt in the Northwest Territories, its potential impact on waterfowl populations, and its value to residents.

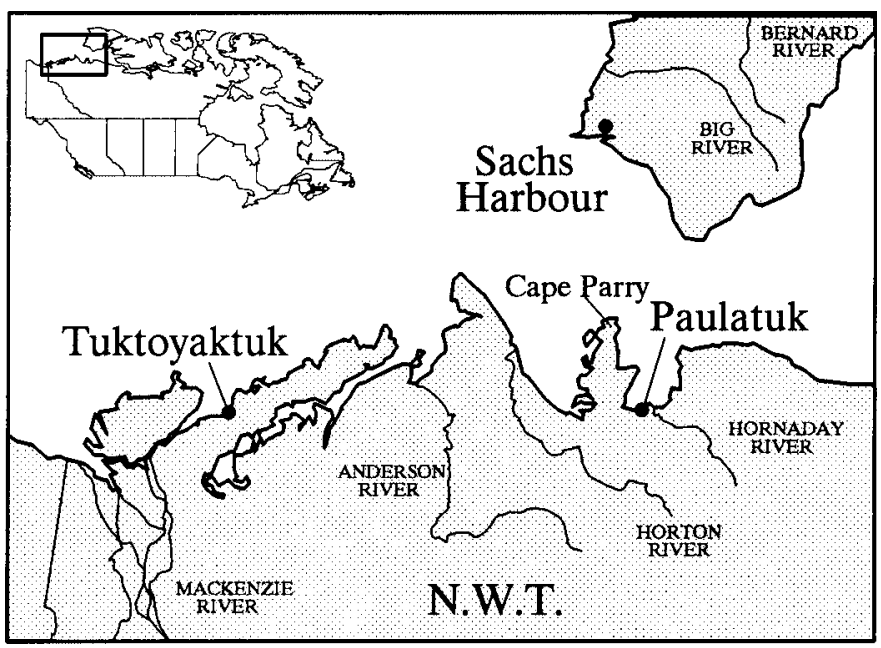

FIG. 1. The Western Arctic, Northwest Territories, indicating the location of communities for which spring waterfowl harvest studies were conducted, 1987-90.

\section{COMMUNITY CHARACTERISTICS}

The three communities are all located on the arctic coast (Fig. 1). Tuktoyaktuk, lying east of the Mackenzie Delta near the base of the Tuktoyaktuk Peninsula, is on one of the major pathways of geese moving either along the Beaufort Coast from the west, or northeast from the Mackenzie River Valley corridor to nearby nesting grounds (Barry and Carpenter, 1983). Paulatuk, near the mouth of the Horton River, benefits from geese migrating either eastward along the coast or to nesting grounds on Banks Island (for lesser snow geese) or in the local area (for white-fronted geese, Canada geese and tundra swans). Sachs Harbour, on the southwestern coast of Banks Island, is located adjacent to the landing and staging area for geese arriving from the mainland and near the nesting colonies $45 \mathrm{~km}$ to the northeast. In 1989, populations were 970 for Tuktoyaktuk, 251 for Paulatuk, and 145 for Sachs Harbour (Northwest Territories Bureau of Statistics, 1990).

Usher (1976) describes the historical background of each community. Sachs Harbour and Paulatuk have local economies based largely upon tourism and renewable resources, while Tuktoyaktuk also relies on the fossil fuel industry for employment opportunities. In 1989, unemployment rates were 35\% for Tuktoyaktuk, 13\% for Paulatuk, and 30\% for Sachs Harbour. Although high compared to those for Canada as a whole, these rates indicate the growing dependence on a wage economy for communities which traditionally have had a subsistence economy. Most residents have a primarily Western Arctic Inuit heritage, but today all communities are a cultural blend of largely western Inuit and Euro-Canadian traditions. More than $90 \%$ of the residents in the communities are Inuvialuit; most of the remainder are nonaboriginal people. Hunters participating in the study were representative of these backgrounds.

\section{METHODS}

The spring harvest by residents of each community was studied in the Tuktoyaktuk area from 1987 to 1989, and in Paulatuk and Sachs Harbour from 1988 to 1990. Before the study, and intermittently throughout, meetings of the local Hunters and Trappers' Committees were attended to explain the study and solicit their input and concerns.

Most spring hunting is conducted from hunting camps situated within $150 \mathrm{~km}$ of the community. An ethnographic approach was adopted: observers often travelled and camped with hunters and their families. One or two community members were hired to accompany each observer, to guide and initially introduce biologists to the hunters. Travel was by snow machine and sled. One team each was sufficient to cover Paulatuk and most of Sachs Harbour, while two teams were required to sample the hunting area of Tuktoyaktuk. As many camps as possible were visited as frequently as possible throughout most of the geographic range of hunters for each community. Upon arriving at a camp or encountering hunters afield, teams visited with people while having tea and bannock, eventually discussing the study. Interviews of hunters and examinations of birds shot were also conducted within each community on an opportunistic basis, and for a day or two after most hunters had returned from the land during spring breakup. Investigators explained that the study was being conducted for two reasons: first, to provide detailed information on the hunt so that government could negotiate an effective spring hunt amendment to the Migratory Bird Convention; and second, to provide biological data on the impact of the spring hunt so that effective regulations could be developed to protect a segment of the resource when conservation measures were required. All hunter-specific data would be confidential, although the results of the study would be published. Hunters were therefore assigned an identification number solely for the purpose of this study, and data were recorded by hunter number. After an opportunity for questions and further discussion about the study, investigators conducted interviews to determine numbers harvested of each species, and when and where the hunt took place (see Questionnaire, Appendix 1). After the interview, teams asked to see birds stored on site, recording species, numbers, sex, and age. Age categories used were yearling $(\leq 12$ months of age) or adult. However, age was not differentiated for Canada geese. Departures from equal sex ratios were detected with chi-square tests when samples were $\geq 5$ (SAS Institute Inc., 1988). When hunters did not mind, teams examined ovarian development in a sample of birds with adult plumage to determine breeding status. Birds with follicles $\geq 10 \mathrm{~mm}$ in diameter were considered to be breeding, while those with follicles $<10 \mathrm{~mm}$ and showing little sign of development were classified as nonbreeders (Wood, 1964). 
In Paulatuk, all hunters were interviewed throughout and at or very close to the end of the spring hunt. Thus the annual figures for Paulatuk are censuses rather than estimates. For Tuktoyaktuk and Sachs Harbour, three estimates of community harvest were made for each species each year. The minimum estimate was the total number of birds shot and reported by those hunters we interviewed. The maximum estimate was calculated as the number of male General Hunting License holders (GHLs) between the ages of 16 and 70 years (from Government of the Northwest Territories files in Yellowknife), times the average harvest of hunters interviewed for each community. All aboriginal residents who hunted game were required by law to possess a General Hunting License, obtainable free from the local Renewable Resource Officer. Essentially all hunters were known to the officers, and thus the expectation that all hunters were licensed was considered valid. For the third and 'most realistic' estimate of the active hunter population, a phone interview of a 15\% random sample of GHLs in Tuktoyaktuk (1987 and 1988) and Sachs Harbour (1988) was conducted to determine what proportion of hunters hunted waterfowl in those years. The average of the 1987 and 1988 estimates was used in 1989 for Tuktoyaktuk, and the 1988 estimate for Sachs Harbour was used for that community in 1989 and 1990 as well. A local hunter estimated that one-third of the active hunter population was less active than the rest, and this seemed to agree with the pattern of hunting activity in individuals that the teams encountered. However, to be most conservative in our harvest estimates, and to minimize the potential bias for encountering the most active hunters, we assumed that all hunters interviewed were active hunters, and that less active hunters harvested one-third of the average harvest of the active sample. This final estimate was the one used in subsequent comparisons with regional populations and continental harvests.

Estimated regional harvests of lesser snow geese, whitefronted geese, Canada geese, and tundra swans were compared to their regional population estimates and to continental harvests of the regional populations. Uncorrected population estimates from $13600 \mathrm{~km}^{2}$ of core waterfowl habitat in the Inuvialuit Settlement Region were available for whitefronted geese, Canada geese and tundra swans in 1989 and 1990 (Hines and Westover, 1991). To adjust for visibility bias associated with aerial survey techniques (Graham and Bell, 1968; Bromley et al., 1995), and for parts of the region not surveyed, the mean of the 1989 and 1990 population estimates was doubled. Population estimates for tundra swans were averaged for the two years, and arbitrarily inflated by $25 \%$ to account for areas not surveyed. Nesting lesser snow geese of the region were estimated in 1987 (Kerbes, 1988). The continental population of lesser snow geese, known as the Western Canadian Arctic Population, is the same as the regional population (Subcommittee on White Geese, 1992). A total estimate of the Western Canadian Arctic Population of lesser snow geese was calculated by applying the observed ratio of breeding, adult-plumaged birds (this study) to the number of nesting birds (from Kerbes, 1988) to give an estimate of adult-plumaged geese. To this we applied the proportion of yearlings in the harvest divided by two, to account for their high relative vulnerability in comparison to older birds (Miller et al., 1968), yielding the final population estimate. A continental population estimate for 1992 was used from Nieman and Gollop (1993) for the Mid-continent White-fronted Goose Population. The estimate for Eastern Population Tundra Swans was an average of mid-winter estimates for 1986 through 1989 from the Ad Hoc Tundra Swan Committee (1995); and for Short Grass Prairie Canada Geese, we used the estimate from Sharp (1994). Continental recreational harvests of lesser snow geese were estimated from a band return rate of $3.2 \%$ for adult geese banded and neck-collared on Banks Island and the Anderson River Delta (J. E. Hines, pers. comm. 1995). Assuming a band reporting rate of $40 \%$ (Conroy and Blandin, 1984), the adult harvest rate would be $8 \%$. This rate was inflated an additional $2 \%$ to account for higher harvest rates of young (Miller et al., 1968), yielding a total annual harvest rate of $10 \%$. Continental recreational harvests of other populations were averaged for 1986-87 through 1989-90 from Sharp (1994) for whitefronted geese; from the Central Flyway Waterfowl Technical Committee (1982, with annual updates) for Canada geese; and from the Ad Hoc Tundra Swan Committee (1995) for swans. To compare spring harvests to total continental harvests (recreational plus spring) of regional numbers, a continental recreational harvest rate (harvest/population) was calculated and applied to regional numbers. The relative size of the spring harvest was the spring harvest divided by the total continental harvest (as defined above) of regional numbers. To determine trends in harvest patterns over time, we compared our results to historical data.

Weather data and snowmelt patterns for the months of May and June were examined for the three communities to the extent that data were available. From these, we ordered years in terms of the phenology (date of snowmelt) and mildness or severity (average temperatures during the days of the study each year) of the spring.

\section{RESULTS}

\section{Interviews with Hunters and Examination of Their Kill}

Hunters and Trappers' Committees supported the study in each community. Hunters and their families were extremely hospitable to investigators, with rare exceptions. Many people viewed spring on the land as an important family time, and some were perhaps reluctant participants in the survey itself. Observers remained sensitive to these concerns and attempted to restrict interviews to those times when it was least inconvenient for the hunter.

Observers were present in community hunting areas for $64-100 \%$ (mean of $90 \%$ ) of the reported harvest each year (Table 1). The remaining reported harvest had occurred within days prior to our arrival. Throughout the study, 1129 interviews were conducted. The number of hunters interviewed 
TABLE 1. Dates of observations in each community, each year and percent of reported waterfowl harvest occurring while observers were present in the Western Arctic, Northwest Territories, 1987-90.

\begin{tabular}{lccccr}
\hline Community & Year & Dates & $\begin{array}{c}\text { Observed } \\
\text { Harvest }\end{array}$ & $\begin{array}{c}\text { Reported } \\
\text { Harvest }\end{array}$ & $\%$ \\
\hline Tuktoyaktuk & 1987 & 26 May - 10 June & 1257 & 1975 & 64 \\
& 1988 & 21 May - 7 June & 2886 & 3645 & 79 \\
& 1989 & 13 May - 2 June & 2285 & 2294 & 100 \\
& 1988 & 16 May - 10 June & 1743 & 1876 & 93 \\
Paulatuk & 1989 & 15 May - 7 June & 1333 & 1410 & 95 \\
& 1990 & 18 May - 8 June & 1527 & 1527 & 100 \\
& 1988 & 27 May - 5 June & 2222 & 2374 & 94 \\
Sachs Harbour & 1989 & 27 May - 5 June & 2558 & 2616 & 98 \\
& 1990 & 28 May - 11 June & 1765 & 1921 & 92 \\
\hline \hline
\end{tabular}

TABLE 2. Number of hunters interviewed and frequency of interviews per hunter, by community and year, to determine the spring harvest of waterfowl in the Western Arctic, Northwest Territories, 1987-90.

\begin{tabular}{lcccc}
\hline Community & Year & Interviews & Hunters & $\begin{array}{c}\text { Interviews per } \\
\text { Hunter }\end{array}$ \\
\hline Tuktoyaktuk & 1987 & 113 & 63 & 1.8 \\
& 1988 & 139 & 72 & 1.9 \\
& 1989 & 127 & 61 & 2.1 \\
& All & 379 & 196 & 1.9 \\
Paulatuk & & & & 2.1 \\
& 1988 & 129 & 61 & 2.2 \\
& 1989 & 137 & 62 & 2.4 \\
& 1990 & 132 & 55 & 2.2 \\
Sachs Harbour & 1988 & 398 & 178 & 2.6 \\
& 1989 & 125 & 37 & 3.5 \\
& 1990 & 131 & 36 & 3.6 \\
& All & 352 & 109 & 3.2 \\
\hline \hline
\end{tabular}

ranged from 36 to 72 in each community each year, with an average of 1.9 to 3.2 interviews per hunter per year (Table 2). The increased number of interviews per hunter seen in all communities over the years (Table 2 ) reflected an increasing awareness of and willingness to participate in the study.

We interviewed $46-55 \%$ of the hunters estimated to be fully active in Tuktoyaktuk, and $80-88 \%$ of those in Sachs Harbour (Table 3). All hunters in Paulatuk (Table 2) were interviewed each year. Over the four years of the study, the number of birds reported ranged from 1975 to 7895 (Table 1). Of these, $27-34 \%$ of the birds were examined each year (compare Tables 1 and 4).

\section{Species Composition and Size of the Harvest}

Because few ducks were shot, the study was restricted to characterizing the goose and swan take. The order of abundance of species in the harvest reflected their availability within the region of each community. Thus species composition was similar for Tuktoyaktuk and Paulatuk (Table 5)
TABLE 3. Estimates of the number of spring waterfowl hunters in Tuktoyaktuk and Sachs Harbour, 1987-90, and the percent of fully active hunters interviewed each year.

\begin{tabular}{lcccccc}
\hline \hline Community & $\begin{array}{r}\text { Year } \\
\text { General Hunting } \\
\text { Licence Holders }\end{array}$ & $\begin{array}{c}\text { No. of } \\
\text { Active }^{2}\end{array}$ & & \multicolumn{2}{c}{$\begin{array}{c}\text { Number of } \\
\text { Waterfowl Hunters }\end{array}$} \\
\cline { 4 - 7 } & & & & $\begin{array}{c}\text { Fully } \\
\text { Active }\end{array}$ & $\begin{array}{c}\text { Interviewed } \\
\text { n (\%) }\end{array}$ & $\begin{array}{c}\text { Less } \\
\text { Active }\end{array}$ \\
\hline Tuktoyaktuk & 1987 & 233 & 74.3 & 115 & $63(54.8)$ & 58 \\
& 1988 & 240 & 83.7 & 134 & $72(53.7)$ & 67 \\
& 1989 & 252 & $79.0^{4}$ & 133 & $61(45.9)$ & 66 \\
Sachs Harbouryyyyyy & 1988 & 53 & $78.6^{4}$ & 42 & $37(88.0)$ & - \\
& 1989 & 57 & 78.6 & 45 & $36(80.0)$ & - \\
& 1990 & 57 & 78.6 & 45 & $36(80.0)$ & - \\
\hline \hline
\end{tabular}

${ }^{1}$ Males between 16 and 70 years of age.

${ }^{2}$ Determined from a $15 \%$ random sample of General Hunting Licence holders. Includes "fully active" and "less active" hunters.

${ }^{3}$ One-third of active hunters in Tuktoyaktuk were designated as "less active" (see Methods).

${ }^{4}$ Average of the two previous years for Tuktoyaktuk; the 1988 estimate for Sachs Harbour was also used for 1989 and 1990.

TABLE 4. Numbers of geese and swans examined for age and sex composition of the harvest each year in the Western Arctic, Northwest Territories, 1987-90.

\begin{tabular}{|c|c|c|c|c|c|c|c|c|}
\hline Community & Year & $\begin{array}{c}\text { Lesser } \\
\text { Snow } \\
\text { Goose }\end{array}$ & $\begin{array}{l}\text { White- } \\
\text { fronted } \\
\text { Goose }\end{array}$ & $\begin{array}{l}\text { Canada } \\
\text { Goose }\end{array}$ & Brant & $\begin{array}{l}\text { Tundra } \\
\text { Swan }\end{array}$ & $\begin{array}{l}\text { Ross' } \\
\text { Goose }\end{array}$ & Total \\
\hline \multirow[t]{4}{*}{ Tuktoyaktuk } & 1987 & 261 & 251 & 25 & 113 & 22 & 2 & 674 \\
\hline & 1988 & 566 & 341 & 10 & 70 & 20 & 6 & 1013 \\
\hline & 1989 & 391 & 258 & 28 & 59 & 17 & 1 & 754 \\
\hline & All & 1218 & 850 & 63 & 242 & 59 & 9 & 2414 \\
\hline \multirow[t]{4}{*}{ Paulatuk } & 1988 & 287 & 100 & 53 & 3 & 7 & 9 & 459 \\
\hline & 1989 & 276 & 53 & 52 & 3 & 15 & 0 & 399 \\
\hline & 1990 & 235 & 86 & 101 & 2 & 11 & 11 & 446 \\
\hline & All & 798 & 239 & 206 & 9 & 33 & 20 & 1305 \\
\hline \multirow[t]{4}{*}{ Sachs Harbour } & 1988 & 1010 & 0 & 2 & 19 & 1 & 2 & 1034 \\
\hline & 1989 & 752 & 1 & 1 & 26 & 0 & 0 & 780 \\
\hline & 1990 & 443 & 1 & 2 & 27 & 0 & 0 & 473 \\
\hline & All & 2205 & 2 & 5 & 72 & 1 & 2 & 2287 \\
\hline Combined & All & 4221 & 1091 & 274 & 323 & 93 & 31 & 6033 \\
\hline
\end{tabular}

TABLE 5. Species composition (\%) of the reported spring harvest of waterfowl in the Western Arctic, Northwest Territories, 1987-90.

\begin{tabular}{lcrcccc}
\hline \hline Community & $\begin{array}{c}\text { Lesser } \\
\text { Snow } \\
\text { Goose }\end{array}$ & $\begin{array}{c}\text { White- } \\
\text { fronted } \\
\text { Goose }\end{array}$ & $\begin{array}{c}\text { Canada } \\
\text { Goose }\end{array}$ & Brant & $\begin{array}{c}\text { Tundra } \\
\text { Swan }\end{array}$ & $\begin{array}{c}\text { Ross' } \\
\text { Goose }\end{array}$ \\
\hline Tuktoyaktuk & 51.1 & 36.5 & 2.0 & 7.8 & 2.5 & 0.1 \\
Paulatuk & 59.6 & 20.5 & 16.7 & 0.5 & 2.3 & 0.5 \\
Sachs Harbour & 96.7 & 0.1 & 0.2 & 2.9 & 0.1 & 0 \\
Combined & 69.7 & 19.4 & 4.9 & 4.2 & 1.6 & 0.2 \\
\hline \hline
\end{tabular}

except for Canada geese, which were more common in the Paulatuk area, east of the Tuktoyaktuk Peninsula and inland from the coast. The lesser snow goose was the most abundant 
TABLE 6. Spring waterfowl harvest estimates by community, year and species for the Western Arctic, Northwest Territories, 1987-90.

\begin{tabular}{|c|c|c|c|c|c|c|c|c|}
\hline Community & Year & Parameter $^{1}$ & $\begin{array}{c}\text { Lesser } \\
\text { Snow } \\
\text { Goose }\end{array}$ & $\begin{array}{l}\text { White- } \\
\text { fronted } \\
\text { Goose }\end{array}$ & $\begin{array}{l}\text { Canada } \\
\text { Goose }\end{array}$ & Brant & $\begin{array}{c}\text { Tundra } \\
\text { Swan }\end{array}$ & $\begin{array}{l}\text { Ross' } \\
\text { Goose }\end{array}$ \\
\hline \multirow[t]{12}{*}{ Tuktoyaktuk } & \multirow[t]{3}{*}{1987} & Minimum & 953 & 701 & 39 & 209 & 70 & 3 \\
\hline & & Maximum & 3525 & 2593 & 144 & 774 & 259 & 12 \\
\hline & & Estimate & 2032 & 1495 & 83 & 446 & 149 & 7 \\
\hline & \multirow[t]{3}{*}{1988} & Minimum & 1980 & 1205 & 79 & 308 & 67 & 6 \\
\hline & & Maximum & 6600 & 4018 & 264 & 1027 & 223 & 19 \\
\hline & & Estimate & 4299 & 2617 & 172 & 669 & 145 & 13 \\
\hline & \multirow[t]{3}{*}{1989} & Minimum & 1109 & 979 & 41 & 100 & 64 & 1 \\
\hline & & Maximum & 4581 & 4045 & 169 & 413 & 265 & 5 \\
\hline & & Estimate & 2818 & 2488 & 104 & 254 & 163 & 3 \\
\hline & \multirow[t]{3}{*}{ Mean } & Minimum & 1347 & 962 & 53 & 206 & 67 & 3 \\
\hline & & Maximum & 4902 & 3552 & 192 & 738 & 249 & 12 \\
\hline & & Estimate & 3050 & 2200 & 120 & 456 & 152 & 8 \\
\hline \multirow[t]{4}{*}{ Paulatuk } & 1988 & Estimate & 1216 & 291 & 322 & 6 & 27 & 14 \\
\hline & 1989 & Estimate & 861 & 313 & 184 & 14 & 36 & 2 \\
\hline & 1990 & Estimate & 794 & 380 & 297 & 3 & 45 & 8 \\
\hline & Mean & Estimate & 957 & 328 & 268 & 8 & 36 & 8 \\
\hline \multirow[t]{12}{*}{ Sachs Harbour } & \multirow[t]{3}{*}{ · 1988} & Minimum & 2284 & 2 & 5 & 78 & 5 & 0 \\
\hline & & Maximum & 3272 & 3 & 7 & 112 & 7 & 0 \\
\hline & & Estimate & 2593 & 2 & 6 & 89 & 6 & 0 \\
\hline & \multirow[t]{3}{*}{1989} & Minimum & 2547 & 2 & 5 & 60 & 2 & 0 \\
\hline & & Maximum & 4033 & 3 & 8 & 95 & 3 & 0 \\
\hline & & Estimate & 3184 & 3 & 6 & 75 & 3 & 0 \\
\hline & \multirow[t]{3}{*}{1990} & Minimum & 1843 & 1 & 5 & 72 & 0 & 0 \\
\hline & & Maximum & 2918 & 2 & 8 & 114 & 0 & 0 \\
\hline & & Estimate & 2304 & 1 & 6 & 90 & 0 & 0 \\
\hline & \multirow{3}{*}{ Mean } & Minimum & 2225 & 2 & 5 & 70 & 2 & 0 \\
\hline & & Maximum & 3408 & 3 & 8 & 107 & 3 & 0 \\
\hline & & Estimate & 2694 & 2 & 6 & 85 & 3 & 0 \\
\hline \multirow[t]{3}{*}{ All } & \multirow[t]{3}{*}{ Mean } & Minimum & 4529 & 1292 & 326 & 284 & 105 & 11 \\
\hline & & Maximum & 7890 & 3883 & 468 & 853 & 288 & 20 \\
\hline & & Estimate & 6701 & 2530 & 394 & 549 & 191 & 16 \\
\hline
\end{tabular}

${ }^{1}$ See Methods for description of the three parameters. The parameter "estimate" was considered to be the most realistic estimate of harvest.

species in all community harvests in all years, and accounted for all of the Sachs Harbour harvest except for small numbers of brant. The white-fronted goose was second in importance for both Tuktoyaktuk and Paulatuk.

Estimated harvests varied by community and year (Table 6), with the largest occurring in Tuktoyaktuk, followed by Sachs Harbour and Paulatuk. The mean number of total birds shot and reported per hunter per year varied from 31.4 to 50.6 in Tuktoyaktuk, 22.7 to 30.8 in Paulatuk, and 53.4 to 72.7 in Sachs Harbour (Table 7).

\section{Timing of the Harvest}

The timing and duration of annual community harvests of lesser snow geese and white-fronted geese varied each year (Figs. 2 and 3). Although all harvesting occurred between 7 May and 12 June (37 days), 95\% of each annual harvest occurred during a much more restricted period of $12-21$ $($ mean $=18)$ days in Tuktoyaktuk, $12-17($ mean $=14)$ days in Paulatuk and 11-18 (mean $=14)$ days in Sachs Harbour.
TABLE 7. Per-hunter spring waterfowl harvest estimates by community, year and species for the Western Arctic, Northwest Territories, 1987-90.

\begin{tabular}{|c|c|c|c|c|c|c|c|c|c|}
\hline Community & Year & Parameter & $\begin{array}{c}\text { Lesser } \\
\text { Snow } \\
\text { Goose }\end{array}$ & $\begin{array}{l}\text { White- } \\
\text { fronted } \\
\text { Goose }\end{array}$ & $\begin{array}{l}\text { Canada } \\
\text { Goose }\end{array}$ & a Brant & $\begin{array}{l}\text { Tundra } \\
\text { Swan }\end{array}$ & $\begin{array}{l}\text { Ross' } \\
\text { Goose }\end{array}$ & $\begin{array}{r}\text {, } \\
\text { e } \text { Botal } \\
\end{array}$ \\
\hline \multirow[t]{9}{*}{ Tuktoyaktuk } & 1987 & Mean & 15.1 & 11.1 & 0.6 & 3.3 & 1.1 & 0.1 & 31.4 \\
\hline & & SD & 21.2 & 14.1 & 0.6 & 5.8 & 2.9 & 0.4 & 27.5 \\
\hline & & Range & $0-80$ & $0-68$ & $0-10$ & $0-38$ & $0-18$ & $0-3$ & $0-100$ \\
\hline & 1988 & Mean & 27.5 & 16.7 & 1.1 & 4.3 & 0.9 & 0.1 & 50.6 \\
\hline & & $\mathrm{SD}$ & 37.2 & 18.7 & 2.5 & 10.6 & 1.3 & 0.4 & 44.7 \\
\hline & & Range & $0-195$ & $0-90$ & $0-16$ & $0-52$ & $0-5$ & $0-3$ & $2-225$ \\
\hline & 1989 & Mean & 18.2 & 16.1 & 0.7 & 1.6 & 1.1 & 0.0 & 37.6 \\
\hline & & SD & 20.6 & 24.3 & 1.5 & 3.3 & 1.8 & 0.1 & 37.4 \\
\hline & & Range & $0-800$ & $0-128$ & $0-6$ & $0-14$ & $0-10$ & $0-1$ & $1-180$ \\
\hline \multirow[t]{9}{*}{ Paulatuk } & 1988 & Mean & 19.9 & 4.8 & 5.3 & 0.1 & 0.4 & 0.2 & 30.8 \\
\hline & & $\mathrm{SD}$ & 18.7 & 5.5 & 4.8 & 0.6 & 0.8 & 0.6 & 25.8 \\
\hline & & Range & $0-86$ & $0-20$ & $0-18$ & $0-4$ & $0-3$ & $0-3$ & $0-95$ \\
\hline & 1989 & Mean & 13.9 & 5.1 & 3.0 & 0.2 & 0.6 & 0.0 & 22.7 \\
\hline & & SD & 14.9 & 6.8 & 2.6 & 1.2 & 1.1 & 0.2 & 19.9 \\
\hline & & Range & $0-85$ & $0-32$ & $0-11$ & $0-8$ & $0-4$ & $0-1$ & $0-96$ \\
\hline & 1990 & Mean & 14.4 & 6.9 & 5.4 & 0.1 & 0.8 & 0.2 & 27.8 \\
\hline & & SD & 14.0 & 6.9 & 5.4 & 0.1 & 0.8 & 0.2 & 24.5 \\
\hline & & Range & $0-58$ & $0-37$ & $0-18$ & $0-2$ & $0-3$ & $0-3$ & $0-92$ \\
\hline \multirow{9}{*}{$\begin{array}{l}\text { Sachs } \\
\text { Harbour }\end{array}$} & 1988 & Mean & 61.7 & 0.1 & 0.1 & 2.1 & 0.1 & 0.0 & 64.1 \\
\hline & & $\mathrm{SD}$ & 50.0 & 0.2 & 0.4 & 5.5 & 0.5 & - & 52.9 \\
\hline & & Range & $3-256$ & $0-1$ & $0-2$ & $0-30$ & $0-3$ & - & $3-266$ \\
\hline & 1989 & Mean & 70.8 & 0.1 & 0.1 & 1.7 & 0.1 & 0.0 & 72.7 \\
\hline & & $\mathrm{SD}$ & 56.9 & 0.2 & 0.5 & 2.5 & 0.2 & - & 58.4 \\
\hline & & Range & $1-243$ & $0-1$ & $0-2$ & $0-8$ & $0-1$ & - & $1-251$ \\
\hline & 1990 & Mean & 51.2 & 0.0 & 0.1 & 2.0 & 0.0 & 0.0 & 53.4 \\
\hline & & $\mathrm{SD}$ & 37.8 & 0.2 & 0.4 & 2.6 & - & - & 40.0 \\
\hline & & Range & $1-158$ & $0-1$ & $0-2$ & $0-10$ & - & - & $1-158$ \\
\hline
\end{tabular}

\section{Sex Ratios in the Kill}

Sex ratios in the harvest varied by species, age, and community in several cases (Table 8). Small sample sizes often precluded analyses by year, however, trends were similar to trends reported for years combined. Interestingly, differences between communities tended to dampen total regional differences. For example, although the harvest of adult lesser snow geese in Tuktoyaktuk was consistently biased towards males, the opposite was true in Sachs Harbour. Similarly, while the harvest of yearling white-fronted geese was consistently biased towards females, bias in the harvest of adults was towards males. For brant, the Sachs Harbour harvest of adults was consistently biased towards males, while there was no bias in the Tuktoyaktuk harvest. In other cases, ratios were uneven but very consistent over space and time. For example, sex ratios for adult-plumaged tundra swans were consistently skewed toward females, although samples sizes (Table 4) were often small.

\section{Age Ratios in the Kill}

Age ratios (immature birds:adults) of lesser snow geese and white-fronted geese tended to follow trends similar to 
Tuktoyaktuk LSG

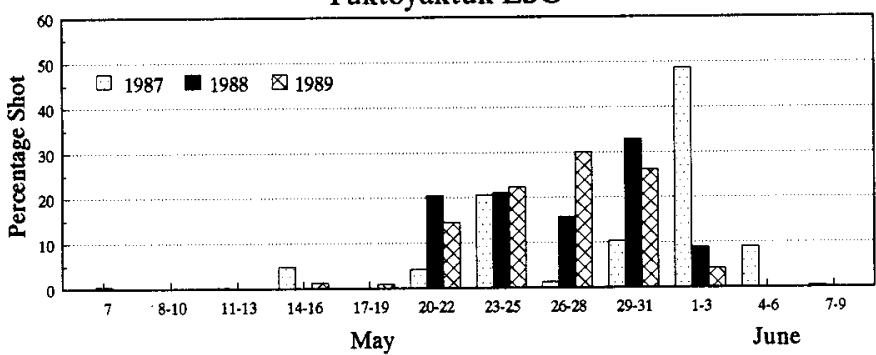

Paulatuk LSG

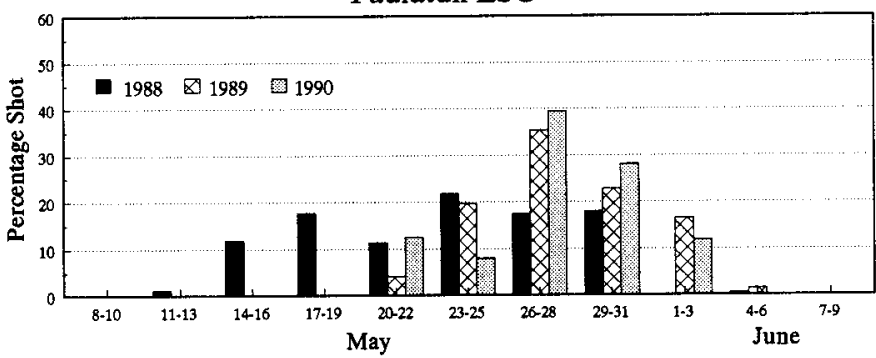

Sachs Harbour LSG

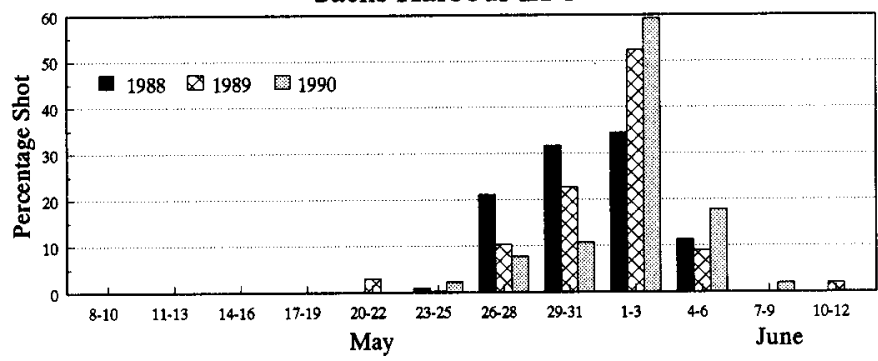

FIG. 2. The timing of the annual reported harvest of lesser snow geese (LSG) in the community hunting areas of Tuktoyaktuk, Paulatuk and Sachs Harbour, Northwest Territories, 1987-90.

TABLE 8. Cases where sex ratios of species by community and age were different from 1:1 (m:f) in the spring waterfowl harvest of the Western Arctic, Northwest Territories, 1987-90.

\begin{tabular}{lllrcc}
\hline \hline Species & Community & Age & N & Ratio (m:f) & $p<$ \\
\hline Lesser Snow Goose & Tuktoyaktuk & adult & 909 & 1.19 & 0.010 \\
& Sachs Harbour & adult & 1672 & 0.87 & 0.005 \\
White-fronted Goose & Tuktoyaktuk & adult & 472 & 1.48 & 0.005 \\
& & yearling & 341 & 0.77 & 0.025 \\
\multirow{2}{*}{ Tundra Swan } & Paulatuk & yearling & 55 & 0.31 & 0.005 \\
Brant & Tuktoyaktuk & adult & 41 & 0.41 & 0.010 \\
& Sachs Harbour & adult & 70 & 1.92 & 0.010 \\
\hline \hline
\end{tabular}

those of the fall continental harvest of those populations (Padding et al., 1993), but were generally lower (Fig. 4). These comparisons are necessarily rough, because the continental harvest is measured for all mid-continent white-fronted geese (Central Flyway) and all Pacific Flyway lesser snow geese, unapportioned to geese from specific breeding regions. Age ratios of white-fronted geese were 1.5 to 7 times those of snow geese, indicating that yearling white-fronted geese were either more vulnerable than yearling snow geese, or that white-fronted geese were more productive over the four years of the study, or both.
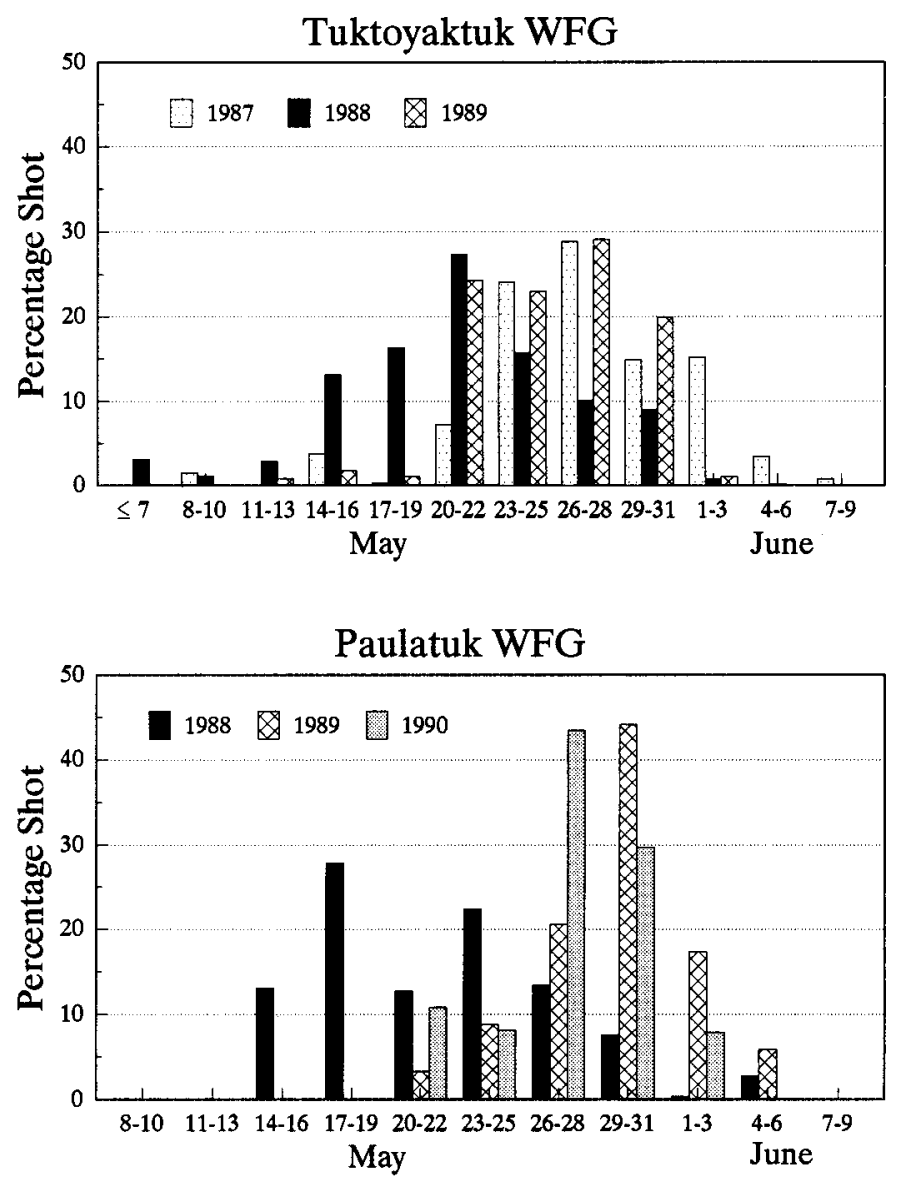

FIG. 3. The timing of the annual reported harvest of white-fronted geese (WFG) in the community hunting areas of Tuktoyaktuk and Paulatuk, Northwest Territories, 1987-90.

\section{Breeding Status}

Of the females in adult plumage examined, white-fronted geese had the largest proportion of breeders, followed by brant, lesser snow geese, Canada geese and tundra swans (Table 9). Insufficient samples of Ross' geese were examined, although breeding Ross' geese were confirmed. A larger proportion of geese tended to be breeders in 1988, an early mild spring, than in other years. For example, in Tuktoyaktuk in 1987, 75-77\% of white-fronted geese and lesser snow geese were breeders, compared to $92-100 \%$ in 1988. An exception was the Paulatuk harvest of lesser snow geese, which contained only $71 \%$ breeders in 1988 .

Of total harvests (i.e., including yearlings), by species, brant (71.7-77.2\% breeders) had the highest proportion of breeding geese, followed by lesser snow geese (62.8-66.0\%), white-fronted geese $(50.2-57.8 \%)$ and tundra swans (31.7$32.6 \%$ ) (Table 10).

\section{Regional Harvest Versus Population Size and Continental Harvest}

Average annual spring harvests for the three communities combined ranged from 1.3\% (tundra swans) to $13.3 \%$ (Canada geese) of regional populations of these species (Table 11). 


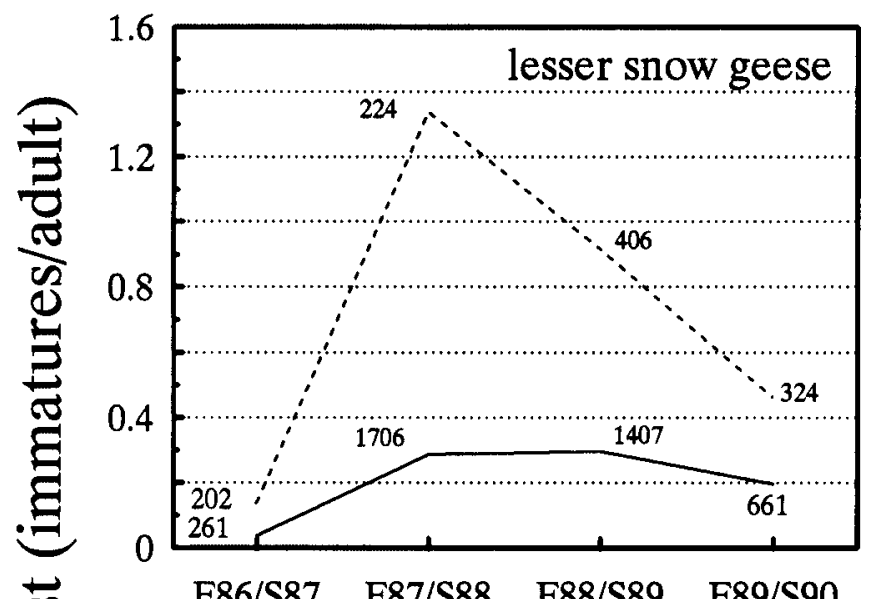

尊

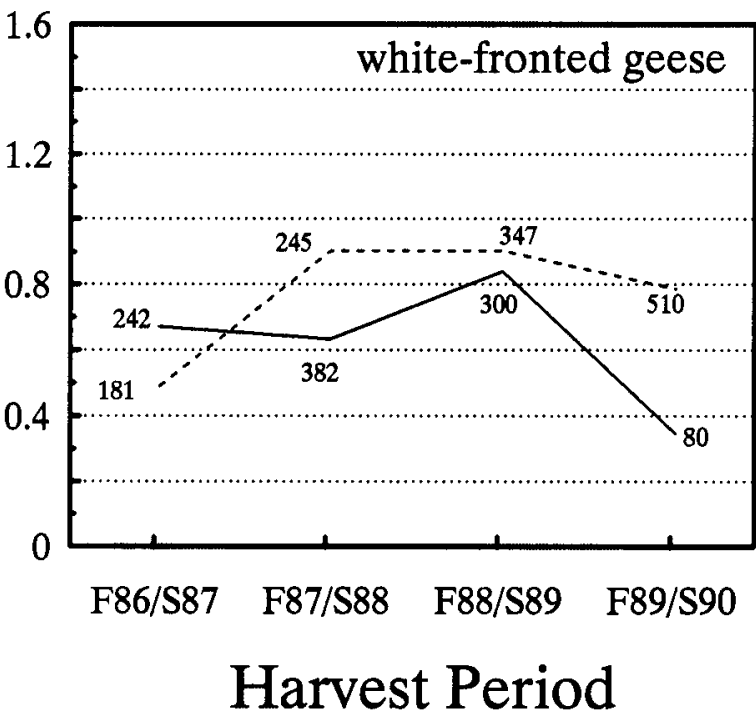

FIG. 4. Age ratios in the Western Arctic spring harvest (- ${ }_{-}$versus the preceding fall/winter harvests (----) of Pacific Flyway lesser snow geese and Mid-continent white-fronted geese, 1987-90. Immatures are birds $\leq$ one year of age. Numbers indicate sample size of harvested birds on which age ratios are based.

The harvests accounted for $15.5 \%$ (white-fronted geese) to $29.6 \%$ (Canada geese) of the total continental harvests of the regional populations.

\section{Trends in Harvest over Time}

Harvests of most species increased several fold between the late 1960s and the late 1980s (Table 12). An exception to this trend was the harvest of lesser snow geese in Tuktoyaktuk, which showed little change. Harvest trends could not be evaluated for brant, which averaged 1077, 114 and 199 birds harvested for Tuktoyaktuk, Paulatuk and Sachs Harbour respectively in 1967 and 1968 (Barry and Carpenter, 1983).

Freeman (1976) described the extent of community hunting areas before people moved into communities in the 1950s and afterwards, in the 1970s, noting that hunting areas contracted somewhat in association with the move from a nomadic life to a more sedentary, community-based life (Fig. 5).
TABLE 9. Breeding status of adult-plumaged females in the spring waterfowl harvest by species, year and community, in the Western Arctic, Northwest Territories, 1987-90.

\begin{tabular}{|c|c|c|c|c|}
\hline Species & Community & Year & $\mathrm{N}^{1}$ & $\%$ Breeding \\
\hline \multirow[t]{5}{*}{ Lesser Snow Goose } & \multirow[t]{2}{*}{ Tuktoyaktuk } & 1987 & 17 & 77 \\
\hline & & 1988 & 13 & 92 \\
\hline & \multirow[t]{2}{*}{ Paulatuk } & 1988 & 34 & 71 \\
\hline & & 1990 & 10 & 90 \\
\hline & All & All & 76 & 79 \\
\hline \multirow[t]{4}{*}{ White-fronted Goose } & \multirow[t]{2}{*}{ Tuktoyaktuk } & 1987 & 12 & 75 \\
\hline & & 1988 & 5 & 100 \\
\hline & Paulatuk & 1988 & 9 & 89 \\
\hline & All & All & 29 & 86 \\
\hline Canada Goose ${ }^{2}$ & All & All & 13 & 69 \\
\hline \multirow[t]{2}{*}{ Brant } & Tuktoyaktuk & 1987 & 23 & 78 \\
\hline & All & All & 25 & 80 \\
\hline Tundra Swan & All & All & 6 & 33 \\
\hline
\end{tabular}

${ }^{1}$ Sample size for "all" categories include birds from years not reported because of small sample size.

${ }^{2}$ Age could not be determined, so sample includes yearlings.

TABLE 10. Percent breeding birds in total spring harvests (yearlings included) of waterfowl by species, year and community in the Western Arctic, Northwest Territories, 1987-90.

\begin{tabular}{lccccc}
\hline Community & Year & $\begin{array}{c}\text { Lesser } \\
\text { Snow } \\
\text { Goose }\end{array}$ & $\begin{array}{c}\text { White- } \\
\text { fronted } \\
\text { Goose }\end{array}$ & Brant & $\begin{array}{c}\text { Tundra } \\
\text { Swan }\end{array}$ \\
\hline \multirow{2}{*}{ Tuktoyaktuk } & 1987 & 76.0 & 52.2 & 74.8 & 31.2 \\
& 1988 & 69.0 & 52.1 & 65.9 & 30.9 \\
& 1989 & 53.1 & 46.3 & 74.4 & 33.0 \\
& Mean & 66.0 & 50.2 & 71.7 & 31.7 \\
Paulatuk & 1988 & 60.6 & 56.8 & - & 31.7 \\
& 1989 & 67.6 & 49.1 & - & 33.0 \\
& 1990 & 65.6 & 67.5 & - & 33.0 \\
Sachs Harbour & 1988 & 58.0 & - & 71.6 & - \\
& 1989 & 64.7 & - & 80.0 & - \\
& 1990 & 65.8 & - & 80.0 & - \\
& Mean & 62.8 & - & 77.2 & - \\
\hline \hline
\end{tabular}

\footnotetext{
${ }^{1}$ Small sample sizes precluded annual estimates for brant in Paulatuk.
}

However, by the late 1980s, old traditional hunting areas were largely reoccupied and in some cases extended beyond those of the 1950s.

\section{Harvests in Relation to Spring Phenology}

The spring of 1987 was classified as the severest, followed by those of 1989 and 1990; with 1988 having the mildest spring of the series (Table 13, Fig. 6). Harvests of lesser snow geese and Canada geese tended to increase with earlier spring phenology in Tuktoyaktuk and Paulatuk, as did harvests of white-fronted geese in Tuktoyaktuk (Fig. 7). Harvests of tundra swans were not related to spring phenology, nor were the annual harvests of lesser snow geese in Sachs Harbour.

The timing of the harvests (Figs. 2 and 3) was also associated with spring phenology (Table 13, Fig. 6). The very 
TABLE 11. Average spring harvest of selected species of waterfowl in the Western Arctic, Northwest Territories, in relation to regional waterfowl populations and continental harvests, 1987-901.

\begin{tabular}{|c|c|c|c|c|}
\hline Variable & Lesser Snow Goose & White-fronted Goose ${ }^{2}$ & Canada Goose & Tundra Swan \\
\hline Continental Population & Western Arctic & Mid-continent & Short Grass Prairie & Eastern \\
\hline Population Size & 281340 & 625850 & 248225 & 88391 \\
\hline Regional Numbers & 281340 & 53326 & 4118 & 14750 \\
\hline Continental Recreational Harvest & 28134 & 162428 & 78600 & 3398 \\
\hline Spring Harvest & 6701 & 2530 & 549 & 191 \\
\hline Spring Harvest as \% of Regional Population & 2.4 & 4.7 & 13.3 & 1.3 \\
\hline Total Continental Harvest of Regional Numbers & 34835 & 16370 & 1853 & 758 \\
\hline Spring Harvest as $\%$ of Total Continental Harvest of Regional Numbers & 19.2 & 15.5 & 29.6 & 25.2 \\
\hline
\end{tabular}

${ }^{1}$ See methods. Population estimates derived from Kerbes (1988), Subcommittee on White Geese (1992), Hines and Westover (1991), Nieman and Gollop (1993), Ad Hoc Tundra Swan Committee (1995), Sharp (1994) and Central Flyway Waterfowl Technical Committee (1982)

${ }^{2}$ As an example of the methodology, recreational harvest of white-fronted geese (162428) divided by population (625850) yielded a harvest rate of 0.2595 , which applied to regional numbers (53326) gave a harvest of 13840 . Total continental harvest of regional numbers was therefore 13840 plus spring harvest (2530), or 16370. Thus the spring harvest was $15.5 \%(2530 / 16370)$ of regional numbers.

TABLE 12. Estimated spring waterfowl harvests (mean for all years) and percent change from the late 1960s to the late 1980s by species and community in the Western Arctic, Northwest Territories.

\begin{tabular}{|c|c|c|c|c|c|}
\hline Community & Period & $\begin{array}{c}\text { Lesser } \\
\text { Snow } \\
\text { Goose }\end{array}$ & $\begin{array}{l}\text { White- } \\
\text { fronted } \\
\text { Goose }\end{array}$ & $\begin{array}{c}\text { Canada } \\
\text { Goose }\end{array}$ & $\begin{array}{c}\text { Tundra } \\
\text { Swan }\end{array}$ \\
\hline Tuktoyaktuk & $\begin{array}{l}1967-68 \\
1987-89 \\
\% \text { change }\end{array}$ & $\begin{array}{r}3255 \\
3050 \\
-6\end{array}$ & $\begin{array}{r}556 \\
2200 \\
+296\end{array}$ & $\begin{array}{r}8 \\
120 \\
+1400\end{array}$ & $\begin{array}{r}23 \\
152 \\
+561\end{array}$ \\
\hline Paulatuk & $\begin{array}{l}1968 \\
1988-90 \\
\% \text { change }\end{array}$ & $\begin{array}{r}335 \\
957 \\
+186\end{array}$ & $\begin{array}{r}119 \\
328 \\
+176\end{array}$ & $\begin{array}{r}5 \\
268 \\
+5260\end{array}$ & $\begin{array}{r}19 \\
36 \\
+89\end{array}$ \\
\hline Sachs Harbour & $\begin{array}{l}1967-68 \\
1988-90 \\
\% \text { change }\end{array}$ & $\begin{array}{r}839 \\
2694 \\
+221\end{array}$ & $\begin{array}{l}0 \\
0 \\
0\end{array}$ & $\begin{array}{l}0 \\
0 \\
0\end{array}$ & $\begin{array}{l}0 \\
0 \\
0\end{array}$ \\
\hline All & $\begin{array}{l}1967-68 \\
1987-89 \\
\% \text { change }\end{array}$ & $\begin{array}{r}4429 \\
6701 \\
+51\end{array}$ & $\begin{array}{r}675 \\
2528 \\
+275\end{array}$ & $\begin{array}{r}13 \\
388 \\
+2885\end{array}$ & $\begin{array}{r}42 \\
188 \\
+348\end{array}$ \\
\hline
\end{tabular}

late and protracted spring of 1987 likely accounted for the extended period of harvest by Tuktoyaktuk hunters that year, compared to the subsequent two years, while the very early spring of 1988 precipitated the earliest harvests in all three communities.

\section{DISCUSSION}

\section{Social Science Considerations}

Response Biases: Non-response bias is an important source of error in questionnaire surveys, perhaps more important than sampling errors (Filion, 1980; Usher and Wenzel, 1987). Filion (1980) concluded that it often results in overestimates of harvest; however, others found it causes underestimates (Tobias and Kay, 1994). Possibly, these contrasting results occur in studies of legal (recreational) versus illegal (spring)
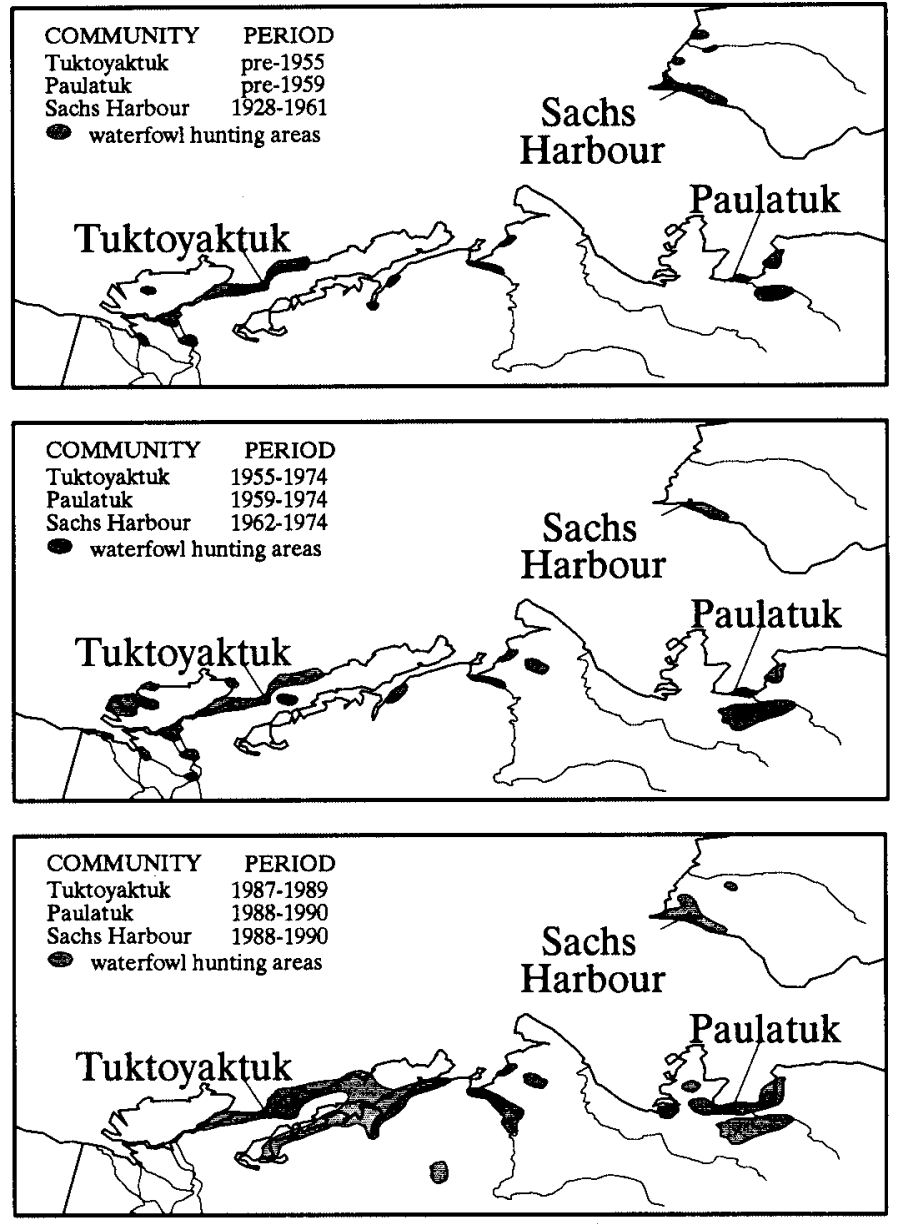

FIG. 5. Locations of Western Arctic spring waterfowl hunting prior to residents' settling in communities $(\leq 1961)$, compared to the period of community settlement (mid-to-late 1950s to 1974), and to the period of this study, 1987-90. Data prior to this study are from Freeman (1976).

harvests, respectively. Filion recommended dealing with non-response bias by reducing non-response and by weighting data. In this study, a large sample of hunters was interviewed (generally $>50 \%$ ) and extra time was taken to solicit 
TABLE 13. Weather data ${ }^{1}$ for Tuktoyaktuk (15 May - 8 June), Paulatuk (15 May - 5 June), and Sachs Harbour (25 May - 8 June), Northwest Territories, during the spring waterfowl hunt, 1987-90, and difference of May mean monthly temperatures from long-term means (i.e., Normal).

\begin{tabular}{lcccc}
\hline Community & Year & $\begin{array}{c}\text { Mean } \\
\text { Temperature } \\
\left({ }^{\circ} \mathrm{C}\right)\end{array}$ & $\begin{array}{c}\text { May } \\
\text { Temperature }\left({ }^{\circ} \mathrm{C}\right)\end{array}$ & $\begin{array}{c}\text { Precipitation } \\
\text { Diff. from Normal }\end{array}$ \\
\hline Tuktoyaktuk & 1987 & -3.0 & -2.5 & 1.6 \\
& 1988 & +1.0 & +1.2 & 8.0 \\
& 1989 & 0.1 & 0.0 & 1.3 \\
Paulatuk & 1988 & -3.2 & -0.8 & 5.0 \\
& 1989 & +1.6 & -2.7 & 0.3 \\
& 1990 & -4.1 & -0.1 & 4.9 \\
Sachs Harbour & 1988 & -0.2 & 0.0 & 6.1 \\
& $1989^{2}$ & -5.9 & -2.3 & 0.3 \\
& $1990^{2}$ & -0.1 & +2.1 & 0.2 \\
\hline \hline
\end{tabular}

${ }^{1}$ Unpublished data from Arctic Weather Centre, Atmospheric Environment Service, Environment Canada, Edmonton, Alberta.

${ }^{2}$ Data available for only 5 days in May in 1989 and 8 days in May and June in 1990.

their participation. Few hunters, usually two or three per community, refused to participate, or did so reluctantly or inconsistently. Finally, in Tuktoyaktuk, results were weighted by active or less active hunters.

Interviewer-induced response bias was unknown. Five interviewers participated in the study; the skills of three were judged to be excellent, one moderate, and one poor. Problems with interviewers were cultural. One whose first language was French had more problems communicating than did the English-speaking interviewers. Another interviewer who was from the region found it difficult to question residents on their harvest. The numbers of interviews provided by these investigators reflected their skills; very few interviews were provided by the unskilled interviewer.

Strategic response bias was almost certainly a factor in the reported harvest of tundra swans and, to a lesser degree, of other waterfowl. The reason for the reluctance to report harvest of swans is unknown. Possibly because this is a new harvest, hunters were less secure in feeling their right to harvest. In general, however, there was often concern that the study would simply result in quotas, and hunters did not feel that their harvest warranted such restrictions. This concern was commonly given as the reason for non-response as well. While non-Native hunters were few, they were also more reluctant to be interviewed than were Native hunters.

Requests from the community Hunters and Trappers' Committees during the course of the work resulted in two changes. First, attempts to measure hunting effort were eliminated. Hunters found questions about the number of days hunted and shotgun shells expended to be awkward when combined with questions on harvest to date. Second, necropsy of carcasses to examine ovarian development in adult females was minimized. Birds shot were typically stored whole, still fully feathered and with gut contents
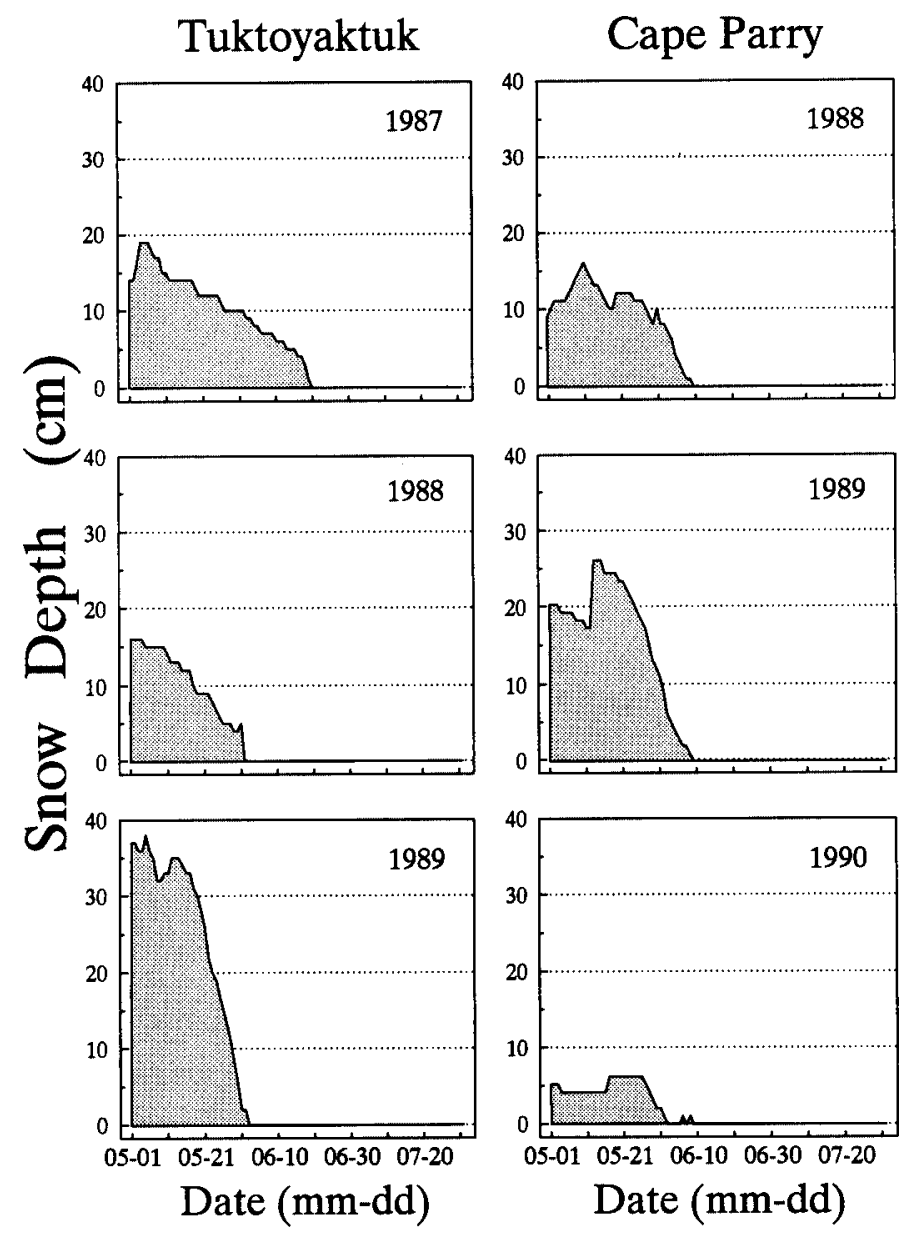

FIG. 6. Patterns of spring snowmelt at Tuktoyaktuk and Cape Parry (between Paulatuk and Sachs Harbour, see Fig. 1), Northwest Territories, 1987-90.

intact. Apparently, the side opening in the cavity of the birds may have caused the taste of the meat to change, and certainly it was not aesthetically pleasing to have intact birds punctured. Thus, measures of ovarian development were conducted opportunistically.

Because hunters were reluctant to report the take of tundra swans, the reported harvest is viewed with low confidence. The presence of teams in camps as swans were brought in enabled several such occurrences to be recorded that otherwise might not have been. In candid conversations, however, a few hunters mentioned that most families like to have a few swans for special occasions, but because their storage requires much freezer space, hunters rarely take more than three to five birds each spring.

In Sachs Harbour several hunters underreported their take. This became apparent when, unbeknownst to the hunter, teams observed shot birds that had accumulated being transported into town by family members of the hunter. Occasionally, hunters hunting in pairs and interviewed independently would report much smaller numbers for themselves than for their partners. On the basis of these observations, we concluded that the reported harvest for Sachs Harbour was clearly a minimum figure. Because Sachs Harbour hunters take more geese on a per hunter 


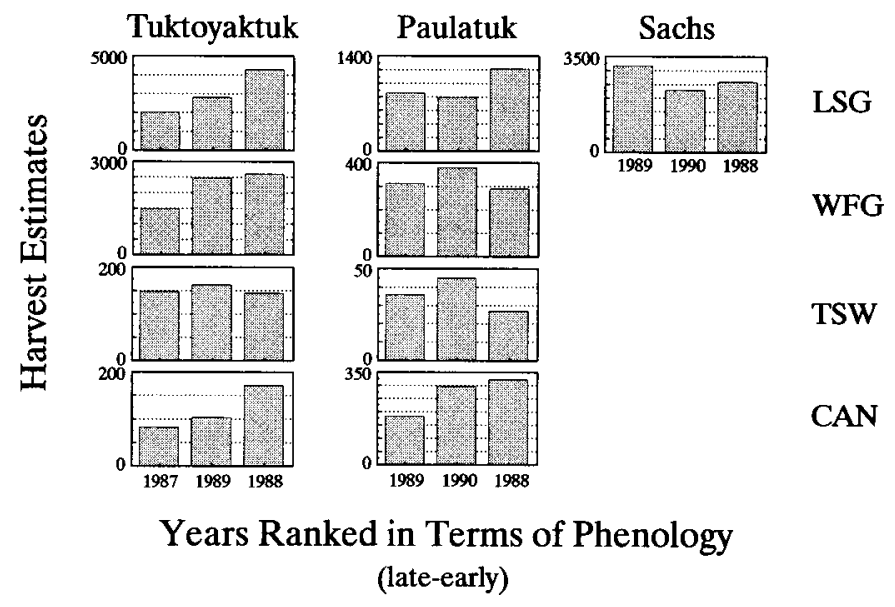

FIG. 7. Estimated annual community harvests of geese and swans in relation to annual spring phenology of three Inuvialuit communities in the Western Arctic, Northwest Territories, 1987-90.

basis than do those of other communities, they may be sensitive to reporting actual numbers taken.

Timing of Surveys in Relation to Harvest: Observers left each community when hunting activity dropped off dramatically. Hunting declined when travel conditions rapidly deteriorated, forcing hunters to return to the community or remain on the land for breakup. Because few chose to remain on the land, the great majority of the harvest was represented, with one exception. Because the brant migration occurred largely after observers had left, the harvest of this species was underestimated. Hunters reported making special trips for brant after observers departed, and hunting opportunistically where brant could be taken close to the community during breakup.

\section{Biological Considerations}

Harvest Rates: Harvest estimates were much higher for Tuktoyaktuk and Sachs Harbour than estimates derived in the Inuvialuit Harvest Study (Fabijan, 1991a,b,c), but they were very similar for Paulatuk, where $100 \%$ coverage of hunters was achieved (see Bromley, 1993 for a comparison of the two studies). However, harvest estimates for Tuktoyaktuk and Sachs Harbour from the present study were still considered conservative because: 1) it was assumed that none of the onethird of hunters who were less active were contacted, whereas a number of this group almost certainly were included in the sample of fully active hunters; 2) estimates do not include final interviews with all of the hunters at the end of each spring; 3) estimates do not include harvest which occurred after the investigators had left the communities; and 4) estimates do not include the harvests of a few very successful hunters (identified through field observations and confidential conversations) who refused to report their harvests or who underreported their spring take. Also, estimates do not include crippling loss, which for fall and winter goose hunting has been estimated at 14-32\% (Florschutz, 1968; United States Fish and Wildlife Service, in Boyd, 1985:6; Nieman et al., 1987).
The size of the spring waterfowl harvest in this region is substantial and has increased since the 1960s, but with the exception of brant, so have continental populations of geese and swans (Bartonek, 1994; Sharp, 1994). However, regional numbers of Ross' geese are unknown, and numbers of brant have declined (Subcommittee on Pacific Brant, 1992). It appears that while populations of lesser snow geese soared throughout North America in the 1980s (Alisauskas and Boyd, 1994; Gamble, 1994; Sharp, 1994), many out of control and to the detriment of their breeding habitat (Cargill and Jefferies, 1984; Kerbes et al., 1990), this particular regional population remained stable (Kerbes, 1986, 1988), at least until 1987. Thus the continental harvest, including the spring hunt in the Inuvialuit region, may have been a factor in limiting the population. Spring harvests accounted for about $19 \%$ of the continental harvest, or $2.4 \%$ of the Western Canadian Arctic Population; however, a recent survey indicated that the population had doubled between 1987 and 1995 (R. Kerbes, pers. comm. 1995). Therefore it is likely that the spring hunt accounted for a declining annual proportion of the regional population as numbers increased during the course of this study. Prevett et al. (1983) determined that the spring and fall harvest by Cree of the Hudson Bay Lowlands accounted for $7 \%$ of the annual harvest of the mid-continent population of lesser snow geese.

Recent aerial surveys have begun to set a baseline for regional numbers of white-fronted geese (Cole and Hines, 1989; Hines et al., 1990; Hines and Westover, 1991; Hines et al., 1992). These reports await expansion to correct for visibility bias (Graham and Bell, 1968; Bromley et al., 1995) and unsurveyed areas; however, expansions are expected to yield increases similar to those used herein (J.H. Hines, pers. comm. 1995). With the information available now, the spring harvest appears large but sustainable in relation to the regional population estimates and continental harvests of the regional populations.

Less information is available for Canada geese in this area, but the harvest rate (Table 11) indicates that they are a desirable quarry.

During the 1970s and 1980s, the Eastern Population of Tundra Swans increased substantially, though it has recently levelled off (Ad Hoc Tundra Swan Committee, 1995). While the reported harvest has also increased, problems in measuring the harvest, as noted above, make it difficult to interpret changes in actual harvest rates for the region. Nevertheless, it is known that the substantial increase in numbers occurred while the spring hunt continued and while recreational harvest increased from zero in 1982 to over 4000 per year by 1990 (Ad Hoc Tundra Swan Committee, 1995). Regional populations are unknown from the past, but the impression of both residents and biologists is that there has been a dramatic increase in numbers regionally. It appears that the harvest rate of the regional population (both spring and fall/winter), to the extent that it is known, can be maintained, but the recent plateau in the swan population indicates that close monitoring is warranted. 
Factors Affecting the Harvest: There is evidence that harvests may be regulated by the time available to hunt (Hanson and Currie, 1957), by the effects of and efforts to minimize disturbance (Berkes, 1982), and by the numbers available for harvest (Macaulay and Boag, 1974). Hunters typically showed high fidelity to particular hunting areas that were associated with traditional use by their families, often dating back to pre-settlement times. This practice would serve to distribute the hunting effort and minimize disturbance, while also leading to efficient harvests. Although this was not a focus of the study, it seemed that where extended families were large with many hunters, the hunted areas were increasing in size from those traditionally occupied. Hunters have now reoccupied their historical range through the means of improved travel capabilities. If numbers and range of hunters continue to expand as mobility and access to currently unoccupied sites increase, harvests may also continue to increase.

On a per hunter basis, average numbers harvested were similar to those of Cree hunters in the Hudson Bay Lowlands of Ontario (Prevett et al., 1983). Capabilities for handling and storing harvests and need likely contribute to limiting the overall take.

Whereas other studies demonstrated reduced harvests in years of early, rapid springs (Hanson and Currie, 1957; Prevett et al., 1983), harvests in this area were greater in earlier springs or their size appeared unrelated to spring phenology. Unlike more southerly harvests, Western Arctic harvests occurred at or near the terminus of spring migration. Waterfowl arrived early during early springs, and were therefore available until travel conditions deteriorated and hunters returned to communities. Hunters suggested that the geese were awaiting favourable winds or snowmelt prior to their final flight to their nesting areas.

Unique social factors may also have affected the harvest. For example, a mass emigration from many hunting camps into Tuktoyaktuk for the Stanley Cup hockey game was witnessed on 31 May 1987. Similarly, the convening of court with a case very important to the community caused a major decline of spring hunting in Paulatuk in 1988. These events interrupted the spring hunt from one to several days for many hunters, and may even have ended the hunt for some.

Species composition in 1987-90 appeared unchanged from that of the 1960s, with two possible exceptions. The brant harvest may have declined as the regional population declined, but because of difficulties in measuring harvest it was not possible to address this question. Secondly, Ross' geese were not mentioned in the earlier study (Barry and Carpenter, 1983), so the modest harvest measured may be new and may reflect an increasing regional population of Ross' geese.

Data on sex and age composition of the harvest are required to assess the impacts of take on populations and productivity (Bromley, 1987). With the exception of a sample of females examined for ovarian development, it was not possible to differentiate between adult-plumaged nonbreeders and breeders. The harvest of snow geese in Sachs Harbour was biased toward breeding adult females (Table 8); however, even these data may have been biased in favour of males. Adult females were often plucked and stored before the take was examined, so they were often not included in birds examined. Hunters reported selecting breeding females because they were fatter, contained developed follicles (rich in fat), and were easier to pluck and more tender to eat than adult males and yearlings. These birds were most vulnerable to harvest because they had prominent abdominal profiles (Owen, 1981), obvious even in flight. They were likely less agile in escaping because they often carried an egg in the oviduct, and they frequently flew slowly and low to the ground as they arrived at Banks Island after a long overseas passage from the mainland. In contrast, hunters in Tuktoyaktuk (where harvest was biased towards adult males) and Paulatuk (no difference in sex ratios) hunted birds that were still at least a week removed from egg-laying and were migrating through as opposed to arriving in an exhausted state. When hunters in Sachs Harbour were asked during community consultations how they would respond to a request to focus on nonbreeders or males if geese needed protection, they indicated they would rather shoot fewer adult females than select another component of the population.

In Tuktoyaktuk there appeared to be a bias towards yearling female and adult male white-fronted geese. If yearling females were consistently more vulnerable than yearling males over time, an excess of adult males would result and possibly explain the bias towards adult males also observed. Of adult-plumaged birds, white-fronted geese had the highest proportion of breeders. However, white-fronted geese consistently had the highest proportion of yearlings and nonbreeders in the harvest (almost 50\%), likely reflecting high vulnerability of yearlings and consistent, moderate productivity compared to other geese (Brazda, 1994; Solberg, 1994).

The age composition of the spring white-fronted goose harvest in Tuktoyaktuk and Paulatuk was correlated with the size of the previous fall/winter continental harvest $(n=6$ [Tuktoyaktuk and Paulatuk harvests for 3 years each], $\mathrm{r}=$ $0.84, p=0.04)$. As the fall/winter harvest increased, the number and proportion of immatures in the population dropped because of the high vulnerability of young (Miller et al., 1968; Timm and Dau, 1979), leaving a reduced number of yearlings available for spring harvest. For the duration of the study (1986-87 to 1989-90 mid-winter populations), 1986-87 had the smallest continental harvest of mid-continent whitefronted geese (Sharp, 1994); this was also the only year when age ratios were higher in the spring harvest than in the preceding fall/winter hunt. Further, in 1989-90 the continental harvest was very high; spring age ratios were substantially lower than fall/winter age ratios that year. These data also indicate that yearlings are as vulnerable in the spring as juveniles were in the fall/winter hunt.

A similar correlation was not detected with lesser snow geese; however, relationships were clouded by mixing of populations in fall and winter harvest areas. As well, snow geese have a boom-and-bust pattern of annual productivity (Solberg, 1994), so that there is not a consistent annual cohort of young snow geese available for harvest. 
Adult-plumaged females were consistently the largest component of the swan harvest. Adult breeding females may have been more vulnerable because of the extra burden of developing follicles or, like sub-adult females, simply because of their smaller size in relation to the shot size and gauge of shotguns being used. Almost all hunters used 12gauge shotguns with size \#4 shot for all species, as this was often the only shot size stocked in local retail stores. Crippling loss appeared to be high with swans, and males may not have been retrieved at the same rate as females.

\section{Management Implications}

A spring harvest must surely have greater impact upon populations than does a fall/winter harvest, but how much greater is a key question. Modelling analyses will help to assess the problem, using knowledge of species composition and size of harvest assignable to management populations, the sex and age composition of the kill, and the timing and location of harvest relative to the natural history traits of the species. These data will also have immediate application should it become necessary to protect one population from overharvest or, as is increasingly the case today, from overpopulation.

Northern waterfowl harvests such as those described here tend to focus on k-selected species, i.e., long-lived species which do not begin breeding until they are two or more years of age (e.g., geese, swans, and sea ducks). Thus a significant portion of the harvest is composed of nonbreeders, and therefore is not dissimilar to the fall/winter harvest. This is not true for spring harvests of $r$-selected species, i.e., shortlived species such as prairie ducks (mallards, pintails and teal), which typically breed at one year of age (Bellrose, 1980), and it is for these species that much of the early concern about spring hunting arose (Hewitt, 1921).

Other key questions remain. For example, does harvesting a member of a breeding pair during migration or prenesting on the breeding grounds preclude production by the remaining pair member? And what is the impact of the disturbance of harvest on nesting areas?

Barry (1967) determined that lesser snow geese and whitefronted geese that breed on the Western Arctic mainland initiate nesting from late May through mid-June in typical years. This exactly coincides with the timing of decline in the harvest, as measured during this study (Figs. 2 and 3). Also, observers were not aware of any cases where birds were shot while nesting, although some adult females had oviposited before being shot. This was more frequently observed in lesser snow geese on Banks Island, where egg dumping is common prior to initiation of nesting (residents of Sachs Harbour, pers. comm., 1988 and 1989).

With recent progress towards amending the Migratory Birds Convention, a legal spring hunt may be anticipated soon. This new opportunity will occur as management regimes evolve, and before management agencies are fully informed about the hunt. Cooperative wildlife management, involving land claim groups with management responsibilities and working with management agencies, offers the opportunity for sharing of knowledge, management needs and effective management implementation to ensure conservation of the resource (e.g., see Inuvialuit goals and principles for wildlife management [Wildlife Management Advisory Council (NWT), 1991]).

In the Northwest Territories, many co-management structures already exist. The Wildlife Management Advisory Council (NWT), the Nunavut Wildlife Management Board, the Gwich'in Renewable Resource Board, and the Sahtu Renewable Resource Board of the Inuvialuit, Inuit, Gwich'in and Slavey, Hare and Mountain Dene and Métis, respectively, are all functioning. At present, however, there is a need to improve coordination among settlement areas and jurisdictions for management of highly mobile resources such as migratory birds. This is important, because in addition to Western Arctic hunters, hunters from the Gwich'in, Sahtu, and Nunavut settlement areas and unresolved claim areas of the Northwest Territories (and possibly from northern Alberta and Saskatchewan) also harvest these same regional breeding populations in spring.

Given local interest, the size of the harvest relative to regional populations, and the need for effective Canadian participation in continental management, a process is needed to ensure local input to current national and international coordination of migratory bird management. For example, a regional committee or committees composed of a member from each co-management board within the ranges of those species populations of interest, could have a representative participate in national (e.g., Wildlife Directors, and a currently lacking technical forum) and international bodies (e.g., Flyway Councils) to complete the necessary level of management coordination. People participating in the spring hunt could then be involved, from setting population goals to monitoring and achieving management results. Open and innovative discussions to facilitate cooperation with users and management authorities range-wide will finally yield thorough and inclusive management of these populations throughout the year.

\section{ACKNOWLEDGEMENTS}

This study was largely supported by the Inuvialuit Game Council. The Polar Continental Shelf Project, Department of Energy, Mines and Resources, Canada, the Northwest Territories Department of Renewable Resources, and the Science Institute of the Northwest Territories also helped fund the work. The study was made possible by the support of the Tuktoyaktuk, Paulatuk and Sachs Harbour Hunters and Trappers' Committees, and the Wildlife Management Advisory Council (Northwest Territories). The participation and hospitality of the hunters and their families from each community are most gratefully acknowledged.

I thank the many workers who assisted with the project. In particular, Alan Fehr conducted the Paulatuk work and contributed to discussions of and improvements to the study. Linda Graf and Bruno Croft assisted with work and discussions for Tuktoyaktuk. 
Mika Sutherland and Ray Bethke assisted with data analyses. Special recognition is given to local guides Alphonse and Paul Voudrach of Tuktoyaktuk, Jonah Nakimayak of Paulatuk, and David Nasogaluak, Jr. of Sachs Harbour. Alan Fehr, Science Institute of the Northwest Territories (West), and Jim Hines, Canadian Wildlife Service, reviewed an earlier draft of the manuscript.

APPENDIX 1. A sample hunter questionnaire form used in interviews of waterfowl hunters in the western Canadian Arctic, 1987-90.

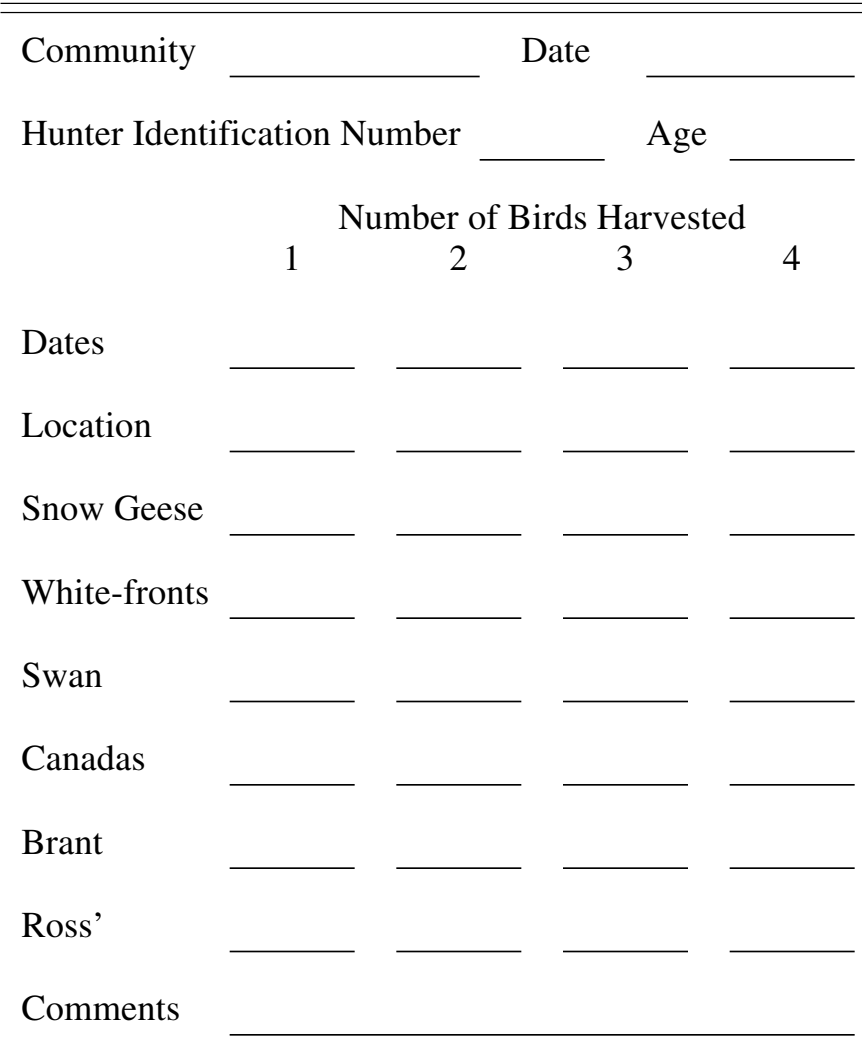

Biologist's name

Location of interview

\section{REFERENCES}

AD HOC TUNDRA SWAN COMMITTEE. 1995. Draft management plan for the eastern population of tundra swans. Unpubl. ms. Available at North Carolina Wildlife Resources Commission, R.R. 4, Box 404-A, Edenton, North Carolina 27932, U.S.A.

ALISAUSKAS, R.T., and BOYD, H. 1994. Previously unrecorded colonies of Ross' and Lesser Snow Geese in the Queen Maud Gulf Bird Sanctuary. Arctic 47:69-73.

ANDERSON, D.R., and BURNHAM, K.P. 1976. Population ecology of the mallard: VI. The effect of exploitation on survival. U.S. Fish and Wildlife Service Resource Publication 128.
ANDERSON, D.R., BURNHAM, K.P., and WHITE, G.C. 1982. The effect of exploitation on annual survival of mallard ducks: An ultrastructural model. Proceedings of the XI International Biometric Conference. Toulouse, France. 11:33-39.

BARRY, T.W. 1967. The geese of the Anderson River Delta, N.W.T. Ph.D. dissertation, University of Alberta, Edmonton.

BARRY, T.W., and CARPENTER, M.E. 1983. The use of birds by Natives in the Mackenzie Delta Region. Unpubl. ms. Available at Canadian Wildlife Service, 4999-98 Avenue, Edmonton, Alberta T6B 2X3.

BARTONEK, J.C. 1994. 1994 Pacific Flyway data book. Unpubl. ms. Available at U.S. Fish and Wildlife Service, 911 NE 11th Avenue, Portland, Oregon 97232-4181, U.S.A.

BELLROSE, F.C. 1980. Ducks, geese and swans of North America. Third edition. Harrisburg, Pennsylvania: Stackpole Books.

BERKES, F. 1982. Waterfowl management and northern Native peoples with reference to Cree hunters of James Bay. Musk-ox 30:23-35.

BOYD, H. 1977. Waterfowl hunting by Native peoples in Canada: The case of James Bay and northern Quebec. International Congress of Game Biologists 13:463-473.

. 1985. The reported kill of ducks and geese in Canada and the USA, 1974-82. Canadian Wildlife Service Occasional Paper 55.

BRACKETT, D. 1995. Letter to Canadian wildlife directors and aboriginal leaders concerning the successful negotiation of a Protocol to amend the Migratory Bird Convention. 18 May, 1995. Available at Canadian Wildlife Service, Ottawa, Ontario K1A 0H3, Canada.

BRAZDA, A.R. 1994. Mid-continent white-fronted geese (Anser albifrons) productivity data. Unpubl. ms. Available at U.S. Fish and Wildlife Service, 210 John Glenn Road, Lafayette, Louisiana, 70508, U.S.A.

BROMLEY, R.G. 1987. Directions for studies of the subsistence waterfowl harvest. Unpubl. ms. Available at Northwest Territories Department of Renewable Resources, Yellowknife, Northwest Territories X1A 3S8, Canada.

1993. Comparison of results from two waterfowl harvest studies in three Inuvialuit communities, Northwest Territories, 1988-1990. Northwest Territorial Department of Renewable Resources File Report No. 111.

BROMLEY, R.G., HEARD, D.C., and CROFT, B. 1995. Visibility bias in aerial surveys relating to nest success of arctic geese. Journal of Wildlife Management 59(2):364-371.

CARGILL, S.M., and JEFFERIES, R.L. 1984. The effect of grazing by lesser snow geese on the vegetation of a sub-Arctic salt marsh. Journal of Applied Ecology 21:669-686.

CENTRAL FLYWAY WATERFOWL TECHNICAL COMMITTEE. 1982. Management guidelines for short grass prairie Canada geese. Updated 1987. Unpubl. ms. Available at U.S. Fish and Wildlife Service, 730 Simms, Golden, Colorado 80401, U.S.A.

COLE, R.W., and HINES, J.E. 1989. Aerial surveys of swans and geese in the Inuvialuit Settlement Region: 1988. Wildlife Management Advisory Council (N.W.T.) Technical Report Number 6. Inuvik, Northwest Territories. 
CONROY, M.J., and BLANDIN, W.W. 1984. Geographic and temporal differences in band reporting rates for American black ducks. Journal of Wildlife Management 48:23-36.

COURNOYEA, N.J., and BROMLEY, R.G. 1986. The role of Native people in waterfowl management in Canada. Transactions of the North American Wildlife and Natural Resources Conference 51:507-510.

ENVIRONMENT CANADA. 1986. North American waterfowl management plan. Available at Canadian Wildlife Service, Ottawa, Ontario K1A 0H3, Canada.

1991. Interim policy on application of the Migratory Birds Convention Act and the Canada Act respecting closed-season hunting and egging by aboriginal people. Available at Canadian Wildlife Service, Ottawa, Ontario K1A 0H3, Canada.

FABIJAN, M. 1991a. Inuvialuit harvest study data report (July 1986-December 1988). Unpubl. ms. Available at Inuvialuit Harvest Study, Box 2120, Inuvik, Northwest Territories X0E 0T0, Canada.

1991b. Inuvialuit harvest study data report (January 1989December 1989). Unpubl. ms. Available at Inuvialuit Harvest Study, Box 2120, Inuvik, Northwest Territories X0E 0T0, Canada.

. 1991c. Inuvialuit harvest study data report (January 1990December 1990). Unpubl. ms. Available at Inuvialuit Harvest Study, Box 2120, Inuvik, Northwest Territories X0E 0T0, Canada.

FILION, F.L. 1980. Human surveys in wildlife management. In: Schemnitz, S., ed. Wildlife management techniques manual. Washington D.C.: The Wildlife Society. 441-453.

FLORSCHUTZ, O., Jr. 1968. Canada goose populations, hunting pressure, kill, crippling loss, and age ratios at Mattamuskeet, North Carolina. In: Hine, R.L., and Schoenfeld, C., eds. Canada goose management: Current continental problems and programs. Madison, Wisconsin: Dembar Education Research Service, Inc. 53-57.

FREEMAN, M.M.R., ed. 1976. Report, Inuit land use and occupancy project. 3 Vols. Ottawa: Department of Indian and Northern Affairs. 263, 287, xvi +153 plates.

GAMBLE, K. 1994. January 1994 waterfowl survey. Unpubl. ms. Available at U.S. Fish and Wildlife Service, 608 E. Cherry Street, Columbia, Missouri 65201-4822, U.S.A.

GRAHAM, A., and BELL, R. 1968. Factors influencing the countability of animals. East African Agricultural and Forestry Journal 34:38-43.

HANSON, H.C., and CURRIE, C. 1957. The kill of wild geese by the natives of the Hudson-James Bay Region. Arctic 10:211229.

HANSON, H.C., and SMITH, R.H. 1950. Canada geese of the Mississippi Flyway with special reference to an Illinois flock. Bulletin of the Illinois Natural History Survey 25(3):67-210.

HEWITT, C.G. 1921. The conservation of the wild life of Canada. New York: Charles Scribner's Sons.

HINES, J.E., and WESTOVER, S.E. 1991. Progress report: Surveys of geese and swans in the Inuvialuit Settlement Region, 1990. Unpubl. ms. Available at Canadian Wildlife Service, Box 637, Yellowknife, Northwest Territories X1A 2N5, Canada.
HINES, J.E., WESTOVER, S.E., and CALLAN, M.F. 1992. Progress report: Surveys of geese and swans in the Inuvialuit Settlement Region, 1991. Unpubl. ms. Available at Canadian Wildlife Service, Box 637, Yellowknife, Northwest Territories X1A 2N5, Canada.

HINES, J.E., WESTOVER, S.E., and KAY, D.G. 1990. Progress report: Surveys of geese and swans in the Inuvialuit Settlement Region, 1989. Unpubl. ms. Available at Canadian Wildlife Service, Box 637, Yellowknife, Northwest Territories X1A 2N5, Canada.

JAMES BAY AND NORTHERN QUEBEC NATIVE HARVESTING RESEARCH COMMITTEE. 1982. The wealth of the land-wildlife harvests by the James Bay Cree, 1972-73 to $1978-79$. Quebec City. 811 p.

KERBES, R.H. 1986. Lesser snow geese, Anser caerulescens caerulescens, nesting in the western Canadian Arctic in 1981. Canadian Field-Naturalist 100:212-217.

1988. Inventory of lesser snow geese nesting in the western Canadian Arctic, June 1987. Unpubl. ms. Available at Canadian Wildlife Service, 115 Perimeter Road, Saskatoon, Saskatchewan S7N 0X4, Canada.

KERBES, R.H., KOTANEN, P.M., and JEFFERIES, R.L. 1990. Destruction of wetland habitats by lesser snow geese: A keystone species on the west coast of Hudson Bay. Journal of Applied Ecology 27:242-258.

KLEIN, D.R. 1966. Waterfowl in the economy of the Eskimos on the Yukon-Kuskokwim Delta, Alaska. Arctic 19:319-336.

LAYCOCK, G. 1985. Doing what's right for the geese. Audubon Magazine 87:119-133.

MACAULAY, A.J., and BOAG, D.A. 1974. Waterfowl harvest by Slave Indians in northern Alberta. Arctic 27:15-26.

MILLER, H.W., DZUBIN, A., and SWEET, J.T. 1968. Distribution and mortality of Saskatchewan-banded white-fronted geese. Transactions of the North American Wildlife and Natural Resources Conference 33:101-119.

NIEMAN, D.J., and GOLLOP, M.A. 1993. Coordinated fall survey of mid-continent white-fronted geese. Unpubl. ms. Available at Canadian Wildlife Service, 115 Perimeter Road, Saskatoon, Saskatchewan S7N 0X4, Canada.

NIEMAN, D.J., HOCHBAUM, G.S., CASWELL, F.D., and TURNER, B.C. 1987. Monitoring hunter performance in Prairie Canada. Transactions of the North American Wildlife and Natural Resources Conference 52:233-245.

NORTHWEST TERRITORIES BUREAU OF STATISTICS. 1990. Population, Northwest Territories, estimates, by region and community, June 1989. Statistics Quarterly 12(2):133. Yellowknife: Northwest Territories Department of Culture and Communications.

OWEN, M. 1981. Abdominal profile-a condition index for wild geese in the field. Journal of Wildlife Management 45:227-230.

PADDING, P.I., MARTIN, E.M., and POWELL, B.H. 1993. Estimates of age and sex compositions of harvested ducks and geese: Preliminary 1992, final 1988-91. Unpubl. ms. Available at U.S. Fish and Wildlife Service, 11500 American Holly Dr., Laurel, Maryland 20708-4016, U.S.A. 
PREVETT, J.P., LUMSDEN, H.G., and JOHNSON, F.C. 1983. Waterfowl kill by Cree hunters of the Hudson Bay Lowland, Ontario. Arctic 36:185-192.

RAVELING, D.G. 1984. Geese and hunters of Alaska's Yukon Delta: Management problems and political dilemmas. Transactions of the North American Wildlife and Natural Resources Conference 45:555-575.

SAS INSTITUTE INC. 1988. SAS users' guide: Statistics. Cary, North Carolina: SAS Institute Inc.

SHARP, D.E. 1994. Central Flyway waterfowl harvest and population survey data, 1992. Unpubl. ms. Available from U.S. Fish and Wildlife Service, 730 Simms, Golden, Colorado, 80401, U.S.A.

SOLBERG, E. 1994. Pacific Flyway goose and swan productivity surveys - 1994. Unpubl. ms. Available at U.S. Fish and Wildlife Service, P.O. Box 1887, Klamath Falls, Oregon 97601, U.S.A.

SUBCOMMITTEE ON PACIFIC BRANT. 1992. Pacific Flyway management plan for Pacific Brant. Pacific Flyway Study Committee. Unpubl. ms. Available at U.S. Fish and Wildlife Service, 911 NE 11th Avenue, Portland, Oregon, 972324181, U.S.A.

SUBCOMMITTEE ON WHITE GEESE. 1992. Pacific Flyway management plan for the Western Arctic population of lesser snow geese. Pacific Flyway Study Committee. Unpubl. ms. Available at U.S. Fish and Wildlife Service, 911 NE 11th Avenue, Portland, Oregon, 97232-4181, U.S.A.

SWERDFAGER, T.M. 1992. Cooperative wildlife management: A discussion paper. Unpubl. ms. Available at Canadian
Wildlife Service, 351 St. Joseph Blvd., Hull, Quebec K1A 0H3, Canada.

THOMPSON, J.G. 1991. Current perspectives on the management of migratory birds in northern Canada and Newfoundland. Transactions of the North American Wildlife and Natural Resources Conference 56:350-357.

TIMM, D.E., and DAU, C.P. 1979. Productivity, mortality, distribution and population status of Pacific Flyway whitefronted geese. In: Jarvis, R.L., and J.C. Bartonek, eds. Management and biology of Pacific Flyway geese. Corvallis, Oregon: Oregon State University Bookstores, Inc. 280-298.

TOBIAS, T.N., and KAY, J.J. 1994. The bush harvest in Pinehouse, Saskatchewan, Canada. Arctic 47:207-221.

USHER, P.J. 1976. Inuit land use in the western Canadian Arctic. In: Freeman, M.M.R., ed. Inuit land use and occupancy project. Vol. 1: Land use and occupancy. 21-31.

USHER, P.J., and WENZEL, G. 1987. Native harvest surveys and statistics: A critique of their construction and use. Arctic 40:145160.

WILDLIFE MANAGEMENT ADVISORY COUNCIL (NWT). 1991. Principles for the conservation of migratory birds in the Inuvialuit Settlement Region. Pamphlet. Available at Wildlife Management Advisory Council, Box 2120, Inuvik, Northwest Territories X0E 0T0, Canada.

WILLIAMS, T. 1986. Spring waterfowling. Gray's Sporting Journal 11(4):45-49.

WOOD, J.S. 1964. Normal development and causes of reproductive failure in Canada geese. Journal of Wildlife Management 28:197-208. 